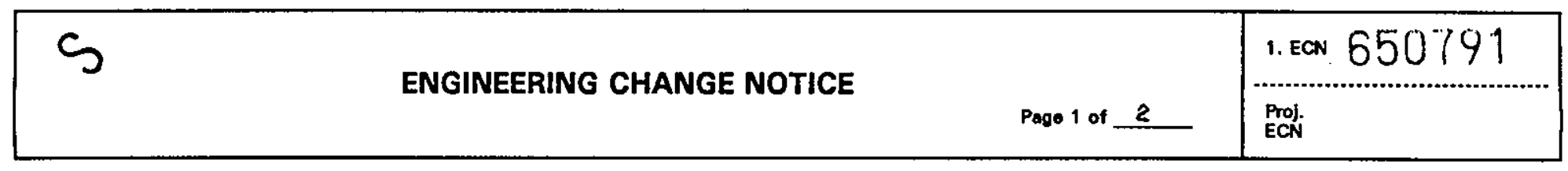

\begin{tabular}{|c|c|c|c|c|}
\hline 2. ECN Category (mark one) & \multicolumn{2}{|c|}{$\begin{array}{l}\text { 3. Originator's Name, Organization, MSIN, and Telephone No. } \\
\text { C. E. Wilson III/LMHC/H7-06/373-6630 }\end{array}$} & $\begin{array}{l}\text { 4. USQ Required? } \\
\text { Yes } \bigcirc \text { No }\end{array}$ & $\begin{array}{l}\text { 5. Date } \\
6 / 28 / 99\end{array}$ \\
\hline $\begin{array}{l}\text { Change ECN } \\
\text { Temporary }\end{array}$ & $\begin{array}{l}\text { 6. Project Title/No. } \text { Work Order No. } \\
\text { RPP TESTING AND EVALUATION } \\
\text { MANAGEMENT PLAN HNE-2029 REV } 1\end{array}$ & $\begin{array}{l}\text { 7. Bldg./Sys./F } \\
\text { NA. }\end{array}$ & & $\begin{array}{l}\text { 8. Approval Designator } \\
\text { NA }\end{array}$ \\
\hline $\begin{array}{l}\text { Standby } \\
\text { Supersedure } \\
\text { CanceiNoid }\end{array}$ & $\begin{array}{l}\text { 9. Document Numbers Changed by this ECN (includes } \\
\text { sheet no. and rev.) } \\
\text { HNF-2029, Revision } 1\end{array}$ & $\begin{array}{l}\text { 10. Related E } \\
\text { NA }\end{array}$ & $\sqrt{\mathrm{No}(\mathrm{s})}$ & $\begin{array}{l}\text { 11. Related PO No. } \\
\text { NA }\end{array}$ \\
\hline $\begin{array}{l}\text { 12a. Modification Work } \\
\text { Yes (fill out Blk. 12b) } \\
\text { No (NA Blks. 12b, } \\
12 \mathrm{c}, 12 \mathrm{~d} \text { ) }\end{array}$ & $\begin{array}{l}\text { 12c. Modification Work Cc } \\
\text { NA } \\
\text { Design Authority/Cog. En } \\
\text { Date }\end{array}$ & eted & $\begin{array}{l}\begin{array}{l}\text { 12d. Restored } \\
\text { or Standk }\end{array} \\
\text { NA } \\
\text { Design Authe }\end{array}$ & $\begin{array}{l}\text { to Original Condition (Temp. } \\
\text { y ECNs only) } \\
\text { rity/Cog. Engineer Signature \& } \\
\text { Date }\end{array}$ \\
\hline
\end{tabular}

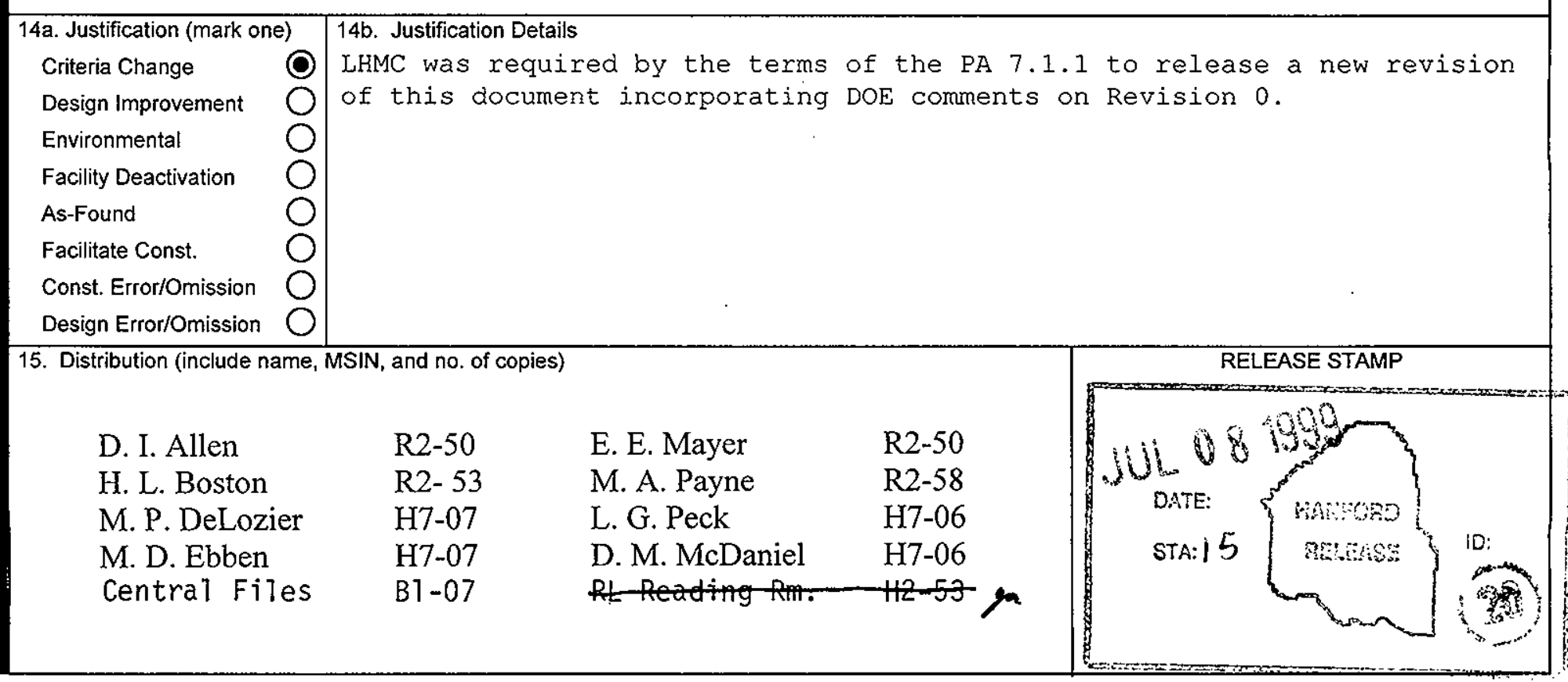


ENGINEERING CHANGE NOTICE

Page 2 of 2

1. ECN (use no. from pg. 1)

650791

16. Design Verification 17 . Cost Impact Required

Yes

No
ENGINEERING

\begin{tabular}{l} 
ENGINEERING \\
Additional $\bigcirc$ \\
Savings $\bigcirc \mathrm{NA}$ \\
\hline
\end{tabular}

CONSTRUCTION

$\begin{array}{ll}\text { Additional } & \$ \mathrm{NA} \\ \text { Savings } & \$\end{array}$
18. Schedule Impact (days)

improvement $\mathrm{N}$ NA

Delay

19. Change Impact Review: Indicate the related documents (other than the engineering documents identified on Side 1) that will be affected by the change described in Block 13. Enter the affected document number in Block 20.

$\begin{array}{ll}\text { SDD/DD } & \\ \text { Functional Design Criteria } & \\ \text { Operating Specification } & \\ \text { Criticality Specification } & \\ \text { Conceptual Design Report } \\ \text { Equipment Spec. } \\ \text { Const. Spec. } \\ \text { Procurement Spec. } \\ \text { Vendor Information } \\ \text { OM Manual } \\ \text { FSAR/SAR } \\ \text { Safety Equipment List } \\ \text { Radiation Work Permit }\end{array}$

Seismic/Stress Analysis
Stress/Design Report
Interface Control Drawing
Calibration Procedure
Installation Procedure
Maintenance Procedure
Engineering Procedure
Operating Instruction
Operating Procedure
Operational Safety Requirement
IEFD Drawing
Cell Arrangement Drawing
Essential Material Specification
Fac. Proc. Samp. Schedule
Inspection Plan
Inventory Adjustment Request

$\square$
$\square$
$\square$
$\square$
$\square$
$\square$
$\square$
$\square$
$\square$
$\square$
$\square$
$\square$
$\square$
$\square$
$\square$

Tank Calibration Manual Health Physics Procedure Spares Multiple Unit Listing Test Procedures/Specification Component Index ASME Coded Item Human Factor Consideration Computer Software Electric Circuit Schedule ICRS Procedure Process Control Manual/Plan Process Flow Chart Purchase Requisition Tickler File NA

20. Other Affected Documents: (NOTE: Documents listed below will not be revised by this ECN.) Signatures below indicate that the signing organization has been notified of other affected documents listed below.

\section{Safety}

Environ. Other
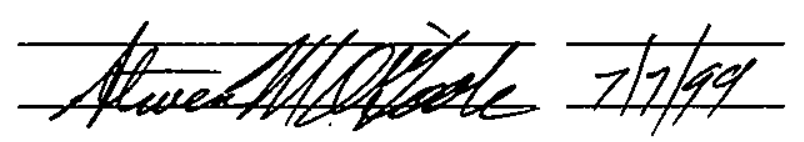

Design Agent

PE

QA

Safety

Design

Environ.

Other

\section{DEPARTMENT OF ENERGY}

Signature or a Control Number that tracks the Approval Signature

ADDITIONAL 


\section{River Protection Project Testing and Evaluation Management Plan}

Prepared for the U.S. Department of Energy RWor Davart KaNrord, we.
Richland, Washington

Hanford Management and Integration Contractor for the

U.S. Department of Energy under Contract DE-AC06-96RL13200 
LEGAL DISCLANMER

This report was prepared as an account of work sponsored by an agency of the United States Government. Neither the United States Government nor any agency thereof, nor any of their employees, nor any of their contractors, subcontractors or their employees, makes any warranty, express or implied, or assumes any legal liability or responsibility for the accuracy, completeness, or any third party's use or the results of such use of any information. apparatus, product, or process disciosed, or represents that its use would not infringe privately owned rights. Reference herein to any specific commercial product, process, or service by trade name, trademark, manufacturer, or otherwise, does not necessarily constitute or imply its endorsement, recommendation, or favoring by the United States Government or any agency thereof or its contractors or subcontractors. The views and opinions of authors expressed herein do not necessarily state or reflect those of the United States Government or any agency thereof.

This report has been reproduced from the best available copy.

Available in paper copy and microfiche.

Available to the U.S. Department of Energy and its contractors from

U.S. Department of Energy

Office of Scientific and Technical Information (OSTI)

P.O. Box 62

Oak Ridge, TN 37831

(615) 576-8401

Available to the public from the U.S. Department of Commerce

National Technical Information Service (NTIS)

5285 Port Royal Road

Springfield, VA 22161

(703) $487-4650$

Printed in the United States of Americe

DISCLM-1.CHP (8-95) 


\title{
RPP TESTING AND EVALUATION MANAGEMENT PLAN
}

\author{
C. E. Wilson III \\ Lockheed Martin Hanford Corporation, Richland \\ Richland, WA 99352 \\ U.S. Department of Energy Contract DE-AC06-96RL13200
}

$\begin{array}{lll}\text { EDT/ECN: } & 650791 & \text { UC: } 2000 \\ \text { Org Code: } & 76000 & \text { Charge Code: } 108676 / \text { AR00 } \\ \text { B\&R Code: } & \text { Ew02J1230 } & \text { Total Pages: } 51\end{array}$

Key Words: Testing, Verification, Systems Engineering, Validation

Abstract: This document describes the system engineering process for imple menting testing and evaluation processes and products within the RPP.

TRADEMARK DISCLAIMER. Reference herein to any specific commercial product, process, or service by trade name, trademark, manufacturer, or otherwise, does not necessarily constitute or imply its endorsement, recommendation, or favoring by the United States Government or any agency thereof or its contractors or subcontractors.

Printed in the United States of America. To obtain copies of this document, contact: Document Control Services, P.O. Box 950, Mailstop H6-08, Richland WA 99352, Phone (509) 372-2420; Fax (509) 376-4989.

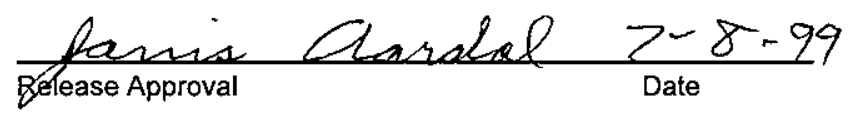

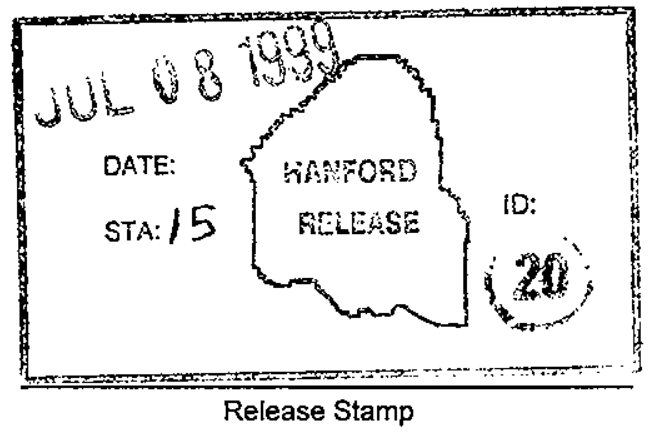


RECORD OF REVISION

(1) Document Number HNE-2029

(2) Title

RPP TESTING AND EVALUATION MANAGEMENT PLAN

Change Control Record

(3) Revision

1
(4) Description of Change - Replace, Add, and Delete Pages

(7)

ORIGINAI RELEASE

RS

REVISION IN RESPONSE TO DOE COMMMENTS PER PA

7.1.1. ECN-650791

Authorized for Release

\begin{tabular}{l|l} 
(5) Cog. Engr. & (6) Cog. Mgr. Date
\end{tabular}

CE Wilson LG Peck

CE Wjispon LG Peck

chlan 7 D $7-7-99$ 
HNF-2029

Revision 1

\section{River Protection Project Testing and Evaluation Management Plan}

Prepared by

Lockheed Martin Hanford Corporation

Date Published

July 1999

Prepared for the U.S. Department of Energy

muen Danina wantoro, wac.

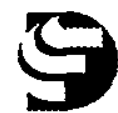

P.O. Box 1000

Richland, Washington

Hanford Management and Integration Contractor for the

U.S. Department of Energy under Contract DE-AC06-96RL13200 
HNF-2029

Revision 1

RIVER PROTECTION PROJECT TESTING AND EVALUATION MANAGEMENT PLAN

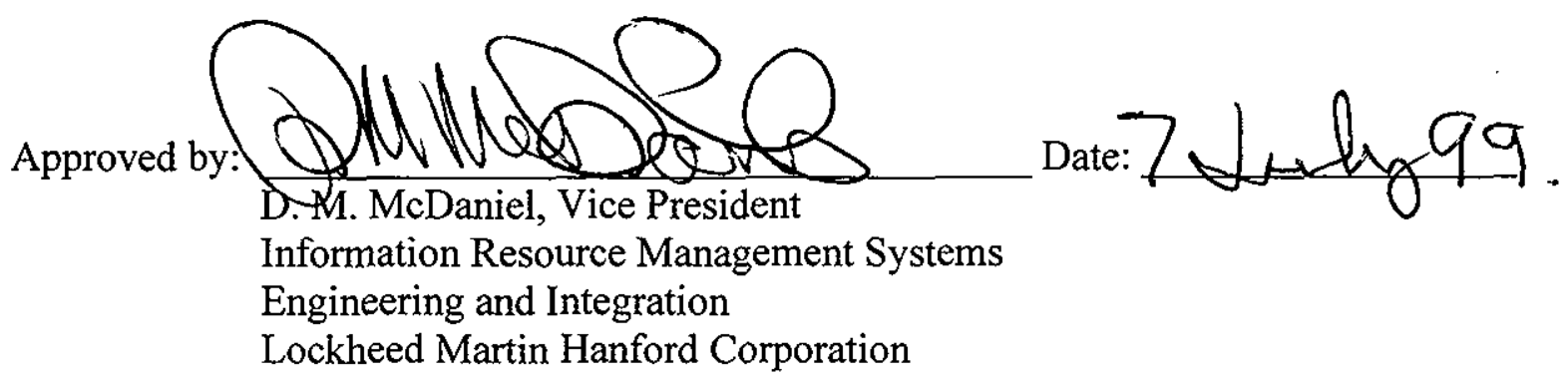


HNF-2029

Revision 1

This page intentionally left blank. 
CONTENTS

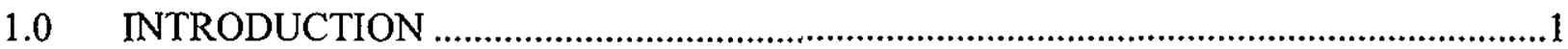

1.1 STANDARD TESTING AND EVALUATION APPROACH ..............................

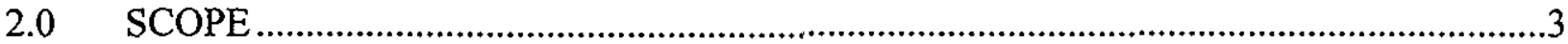

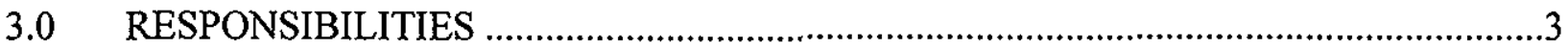

$3.1 \quad$ PROGRAM

$3.2 \quad$ PROJECT .

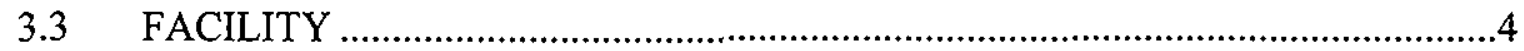

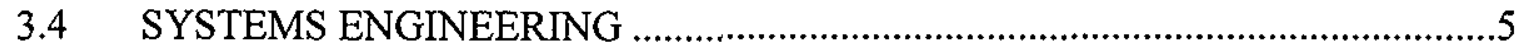

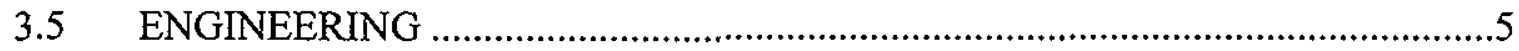

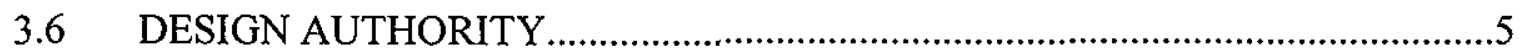

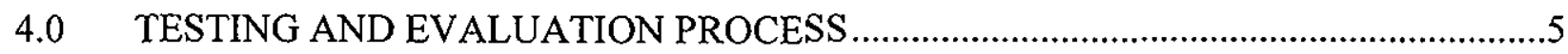

4.1 TESTING AND EVALUATION PLANNING ......................................................

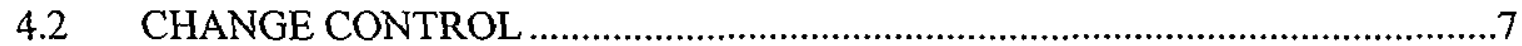

4.2.1 Change Control Process .........................................................................

4.2.2 Baseline Changes Affecting Testing and Evaluation ................................7

4.2.3 Baseline Changes Initiated Within Testing and Evaluation .......................7

4.3 TECHNICAL PERFORMANCE MEASURES ……............................................

4.4 TEST ACCEPTANCE CRITERIA ……….........................................................

4.4.1 Acceptance Criteria Measurability .....................................................

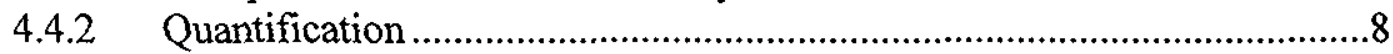

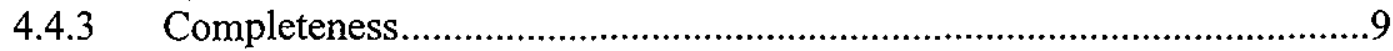

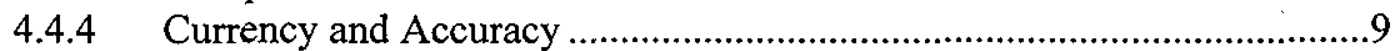

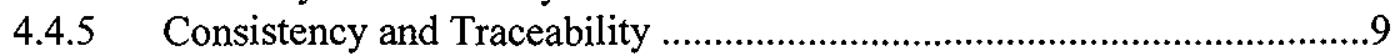

4.4.6 Acceptance Criteria Approval .................................................................9

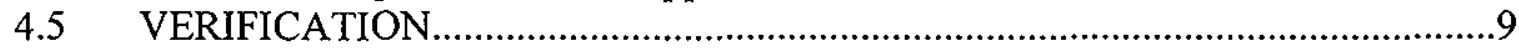

4.5.1 Testing Independence .....................................................................

4.5.2 Verification Methods ..........................................................................10

4.5.3 Development and Design Verification ...................................................10

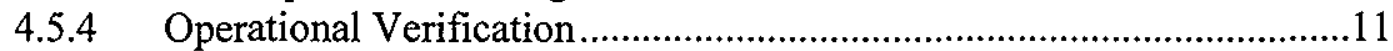

4.5.5 Integration of Verification Results .......................................................11

4.5.6 System Verification................................................................................11

4.6 TESTING AND EVALUATION FOR REQUIREMENTS BASELINE PHASE12

4.6.1 Early Prototype Testing ..................................................................12

4.6.2 Early Prototype Testing Documentation .................................................13

4.7 TESTING AND EVALUATION FOR DESIGN BASELINE PHASE .................13

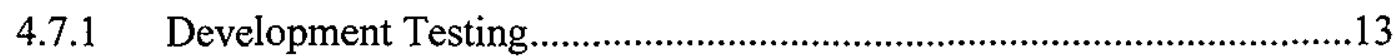

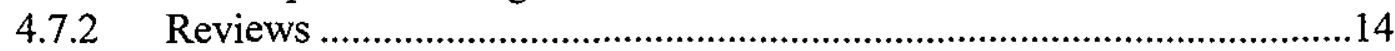

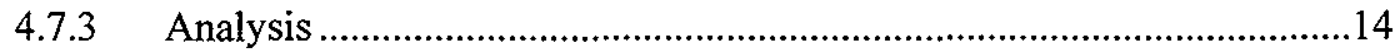

4.7.4 Operational Testing and Evaluation Plan ...............................................14

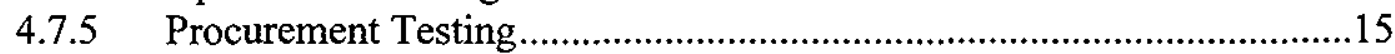

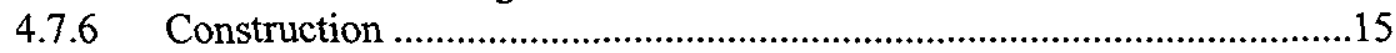

4.7.7 Post-Installation and Pre-Operational Acceptance Testing......................16

4.7.8 Integrated Operational Testing ..........................................................16

4.7.9 Operational Testing at Turnover................................................................17 
HNF-2029

Revision 1

4.8 TESTING AND EVALUATION FOR OPERATIONS BASELINE PHASE.......17

4.8.1 Operations and Maintenance Testing and Evaluation ...............................18

4.8.2 Surveillance Testing ..............................................................................18

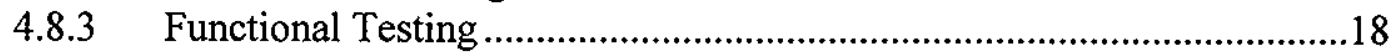

4.8.4 Preventive Maintenance ................................................................18

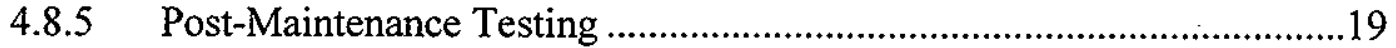

4.8.6 Production/Process Testing ................................................................19

4.8.7 Major Facility/Operational Modifications Testing and Evaluation..........19

4.8.8 Closeout Testing and Evaluation........................................................19

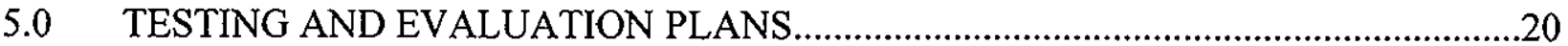

5.1 ISSUES AND RISKS TO BE ADDRESSED BY TESTING AND

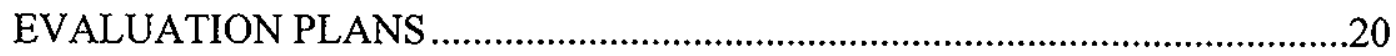

6.0 RIVER PROTECTION PROJECT TESTING AND EVALUATION IMPLEMENTING

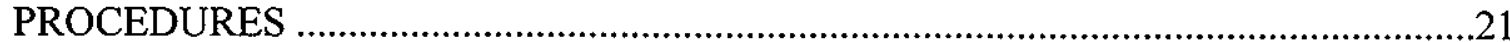

6.1 HNF-IP-0842, TWRS ADMINISTRATIVE MANUAL, TESTING AND

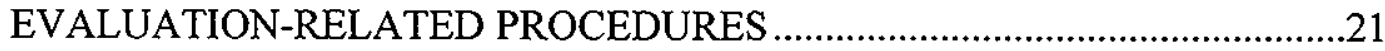

6.1.1 Volume 4, Section 2.12, "Testing and Evaluation"...................................21

6.1.2 Volume I, Section 1.1, "Winterization Plan for 200 Area Tank Farms".21

6.1.3 Volume 1, Section 1.3, "Integration of Operational Readiness and

Readiness Assessment Review Planning in the Project Life Cycle" ......................22

6.1.4 Volume II, Section 4.1.3, "Joint Test Review Process"..........................22

6.1.5 Volume IV, Section 3.12, "Acceptance of Structures, Systems, and Components for Beneficial Use" ......................................................................22

6.1.6 Volume 4, Section 4.24, "Design Verification" ......................................23

6.1.7 Volume 4, Section 4.6, "Functional Tests" ............................................23

6.1.8 Volume 4, Section 4.7, "Process Tests" ...................................................23

6.1.9 Volume 4, Section 4.28, "Testing Practices Requirements" ....................23

6.1.10 Volume IV, Section 2.3, "Design Authority Process, Selection, and

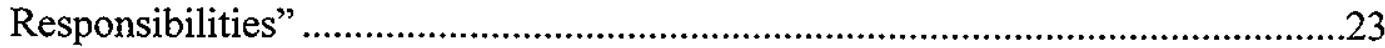

6.1.11 MD-004, "Tank Waste Remediation System Change Control"..............23

6.1.12 MD-14, "Integrated Planning Process and Configuration Control"........24

6.2 PROJECT HANFORD MANAGEMENT CONTRACT - HNF-PRO SERIES

TESTING AND EVALUATION-RELATED PROCEDURES............................24

6.2.1 HNF-PRO-1819, PHMC Engineering Requirements..............................24

6.2.2 HNF-PRO-1997, Construction Program Overview .................................24

6.2.3 HNF-PRO-1998, Construction Program Pre-Conceptual Activity..........25

6.2.4 HNF-PRO-1999, Construction Program Conceptual Phase ...................25

6.2.5 HNF-PRO-097, Engineering Design and Evaluation ..............................25

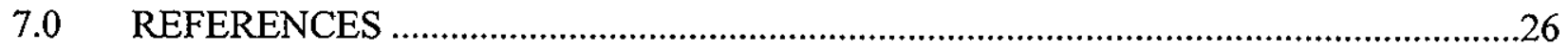

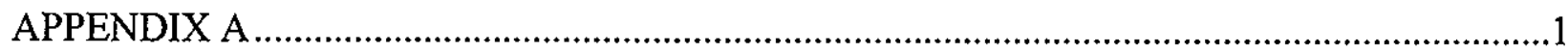

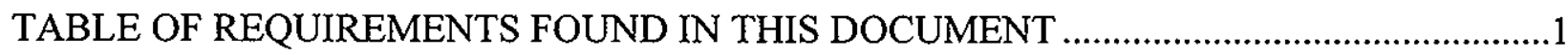

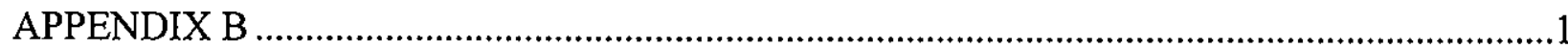

ANNOTATED OUTLINE FOR TESTING AND EVALUATION PLANS ................................... 
HNF-2029

Revision 1

\section{LIST OF FIGURES}

Figure 1. Program/Project Life Cycle............................................................................. 2

Figure 2. Testing and Evaluation Generic Product Tree.........................................................6 6 
HNF-2029

Revision 1

\section{LIST OF TERMS}

$\begin{array}{ll}\text { ATP } & \text { acceptance test procedure } \\ \text { CD } & \begin{array}{l}\text { critical decision } \\ \text { decontamination and decommissioning }\end{array} \\ \text { D\&D } & \text { U.S. Department of Energy } \\ \text { DOE } & \text { functions and requirements } \\ \text { F\&R } & \text { Fluor Daniel Hanford, Inc. } \\ \text { FDH } & \text { operational test procedure } \\ \text { OTP } & \text { Project Hanford Management Contract } \\ \text { PHMC } & \text { River Protection Project } \\ \text { RPP } & \text { systems, structures, and components } \\ \text { SSC } & \text { testing and evaluation } \\ \text { T\&E } & \text { Testing and Evaluation Management Plan } \\ \text { TEMP } & \text { testing and evaluation plan } \\ \text { TEP } & \text { technical performance measure } \\ \text { TPM } & \text { technical safety requirement } \\ \text { TSR } & \text { Tank Waste Remediation System }\end{array}$


HNF-2029

Revision 1

\section{RIVER PROTECTION PROJECT TESTING AND EVALUATION MANAGEMENT PLAN}

\subsection{INTRODUCTION}

Testing and evaluation (T\&E) planning, implementation, and verification activities shall be performed to verify that system(s) (along with their subsystems and components) can be designed, installed, and operated to satisfy their specified source requirements and operational characteristics. T\&E activities shall be conducted throughout each phase of a project's life cycle and during the Operation Baseline Phase (see Figure 1) to minimize risk and provide confidence that the new or modified system(s) will operate as planned.

T\&E includes the complete set of life-cycle activities used to verify that new or modified system(s) will perform their functions and satisfy requirements. T\&E planning and implementation involves a much broader set of activities than just the physical testing of component, subsystems, or systems. A complete T\&E life-cycle approach includes the following:

- Reviews, tests and analysis performed during design/operations/deactivation and decommissioning (D\&D) activities

- Ensuring system effectiveness, usability, supportability, adaptability, compatibility, and interoperability with existing, planned and/or operational facilities

- Inspection activities performed during manufacturing and/or construction activities

- Testing performed during design, manufacturing, construction, turnover and operational activities

- Documentation of acceptance criteria for traceability to requirements.

This Testing and Evaluation Management Plan (TEMP) provides the necessary requirements, guidelines, and process descriptions to formulate and execute an effective T\&E program for the River Protection Project (RPP) program that is traceable to requirements (safety, design, and operation). Appendix A provides a quick reference table of the requirements discussed in this TEMP. Individual RPP programs, projects, and facility operations (where appropriate) will develop testing and evaluation plans (TEP) that describe the T\&E management responsibilities and planned activities required to conduct program/project life-cycle T\&E. 
HNF-2029

Revision 1

Figure 1. Program/Project Life Cycle.

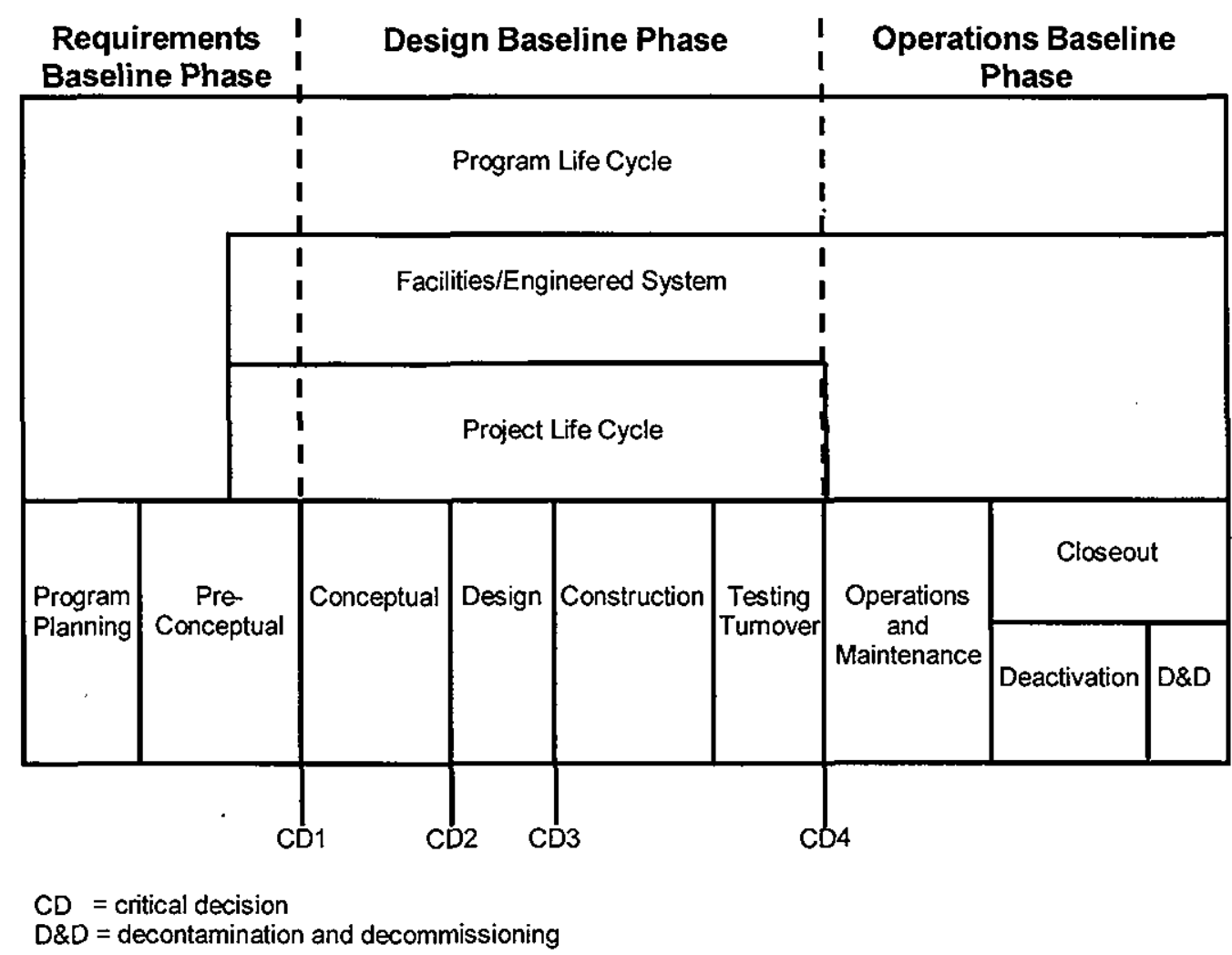

\subsection{STANDARD TESTING AND EVALUATION APPROACH}

A standard testing approach is normally implemented for testing activities. The following steps are the basis for the T\&E process and products presented in this document. This approach is applied at all levels of testing and involves the following steps.

- Planning--This is the first part of the process and ensures that the envisioned testing activities are identified, planned, integrated with other activities, and incorporated into the baseline budget and schedules.

- Execution--After the test activity is planned and included in the baseline, test acceptance criteria and test procedures and/or specifications are developed to guide the execution of the test activity. The test is then initiated and completed.

- Evaluation--Upon completion, test results are evaluated against the test acceptance criteria to determine if the test was successful or limited or if complete re-planning and/or re-testing is required. 
HNF-2029

Revision 1

- Reporting--This is the last step in the standard testing approach and involves the generation of the test-reporting documentation. Documentation records the test results, the evaluation results, and other information determined to be relative.

\subsection{SCOPE}

Programs (e.g., Waste Feed Delivery), construction/capital projects (e.g., W-211), and facility/operations that support the RPP mission are required to have TEPs that define and plan specific T\&E activities. For RPP, operational TEPs do not need to address T\&E activities in the closeout (deactivation) phases because deactivation and D\&D plans and documents typically address these activities.

\subsection{RESPONSIBILITIES}

\subsection{PROGRAM}

The program is responsible for the following:

- Initial planning and ensuring the preparation of the project TEPs in the program's area of responsibility during the generation of the requirements baseline

- Initial planning and integration of T\&E work scope into the appropriate baseline to support reviews identified in HNF-SD-WM-SEMP-002, Tank Waste Remediation System Systems Engineering Management Plan (Peck 1998) and future operational readiness and/or readiness assessment reviews if such reviews will be conducted for the specific program or project (see HNF-IP-0842, TWRS Administrative Manual, Volume I, Section 1.3, "Integration of Operational Readiness and Readiness Assessment Planning in the Project Life Cycle") (Gibson 1998)

- Conducting the development testing and analysis required by each TEP to verify technologies, processes, and design concepts

- Providing general direction to the project managers for development and execution of T\&E activities during the Requirements Baseline and Design Baseline phases. 
HNF-2029

Revision 1

\subsection{PROJECT}

The project is responsible for the following:

- Translating the performance requirements specification(s) into a fully defined design baseline

- Ensuring that performance requirements are achieved for the systems, structures, and components (SSC) within the project's areas of responsibilities

- Designing, constructing/installing, and testing of the physical architecture elements (including software)

- Ensuring that staff conduct all $T \& E$ activities in accordance with the guidelines and standards established in this TEMP, in the project-specific TEPs, and related T\&E procedures

- Integrating $T \& \mathrm{E}$ results into the project issues management list, or appropriate similar list(s), as results become available

- Maintaining and revising the project TEP as needed and preparing the operational TEP (if appropriate to the specific project).

\subsection{FACILITY}

The facility, as the end-user (operations), has the following responsibilities:

- Reviewing and commenting on project requirements submitted by program management

- Reviewing documentation submitted by the project manager for design, "as-built" configuration, T\&E documentation, and supporting infrastructure elements (e.g., operating and maintenance procedures, revised technical safety requirements [TSR], etc.) before accepting the new or modified systems and/or facilities for operational use

- Conducting appropriate facility testing (operational, acceptance, in-service, etc.), procedure validation, and other preparations for operational readiness review and after facility startup.

Participation by the end-user organization in all phases of the baseline development, and in particular in development of the TEP and supporting procedures, is essential to ensure that operations and maintenance requirements and expectations are satisfied. The facility manager and the project manager will coordinate pre-startup and readiness review preparation activities to ensure that required $T \& E$ activities and deliverables are completed on schedule. The facility 
HNF-2029

Revision 1

manager shall ensure that design, testing, and verification independence are established in accordance with procedures.

\subsection{SYSTEMS ENGINEERING}

Systems Engineering staff is responsible for the following:

- Assisting the program, project, and facility managers in implementing the requirements in this TEMP

- Assisting the program, project, and facility managers in generating specific TEPs required by this TEMP

- Reviewing and assessing TEPs and appropriate $T \& E$ products and results to ensure consistent implementation of the processes discussed in this TEMP

- Generating T\&E policy.

\subsection{ENGINEERING}

T\&E engineering activities, responsibilities, and products shall be implemented as specified in HNF-PRO-1819, PHMC Engineering Requirements, and HNF-IP-0842, Volume 1, Section 3.30, "TWRS Technical Operations and Engineering Charter."

\subsection{DESIGN AUTHORITY}

The T\&E activities, responsibilities, and products required from the design authority shall be implemented as specified in HNF-PRO-1819, PHMC Engineering Requirements, and HNF-IP-0842, Volume IV, Section 2.3, "Design Authority Roles and Responsibilities."

\subsection{TESTING AND EVALUATION PROCESS}

This section presents guidance and requirements for T\&E activities and planning during the life cycle of the program, project, and facility operations. Along with this guidance, T\&E planning and implementation activities shall include the $T \& E$ engineering requirements provided in HNF-PRO-1819, PHMC Engineering Requirements.

\subsection{TESTING AND EVALUATION PLANNING}

RPP T\&E planning begins with the development of the RPP mission analysis report and program-level functions and requirements (F\&R). T\&E planning continues through $F \& R$ 
development; specification development; architecture selection; and conceptual and detailed design, construction, and operations phases; and ends with facility deactivation (see Figure 1). $T \& E$ activities shall be traceable to requirements.

The T\&E planning processes and identified products shall be incorporated into the appropriate baseline documentation commensurate with the complexity, risk, and visibility of the program, project, or operational activity. Figure 2 presents a generic product tree of key T\&E products that would apply in most situations during the Requirements Baseline and Design Requirements Baseline phases.

Figure 2. Testing and Evaluation Generic Product Tree.

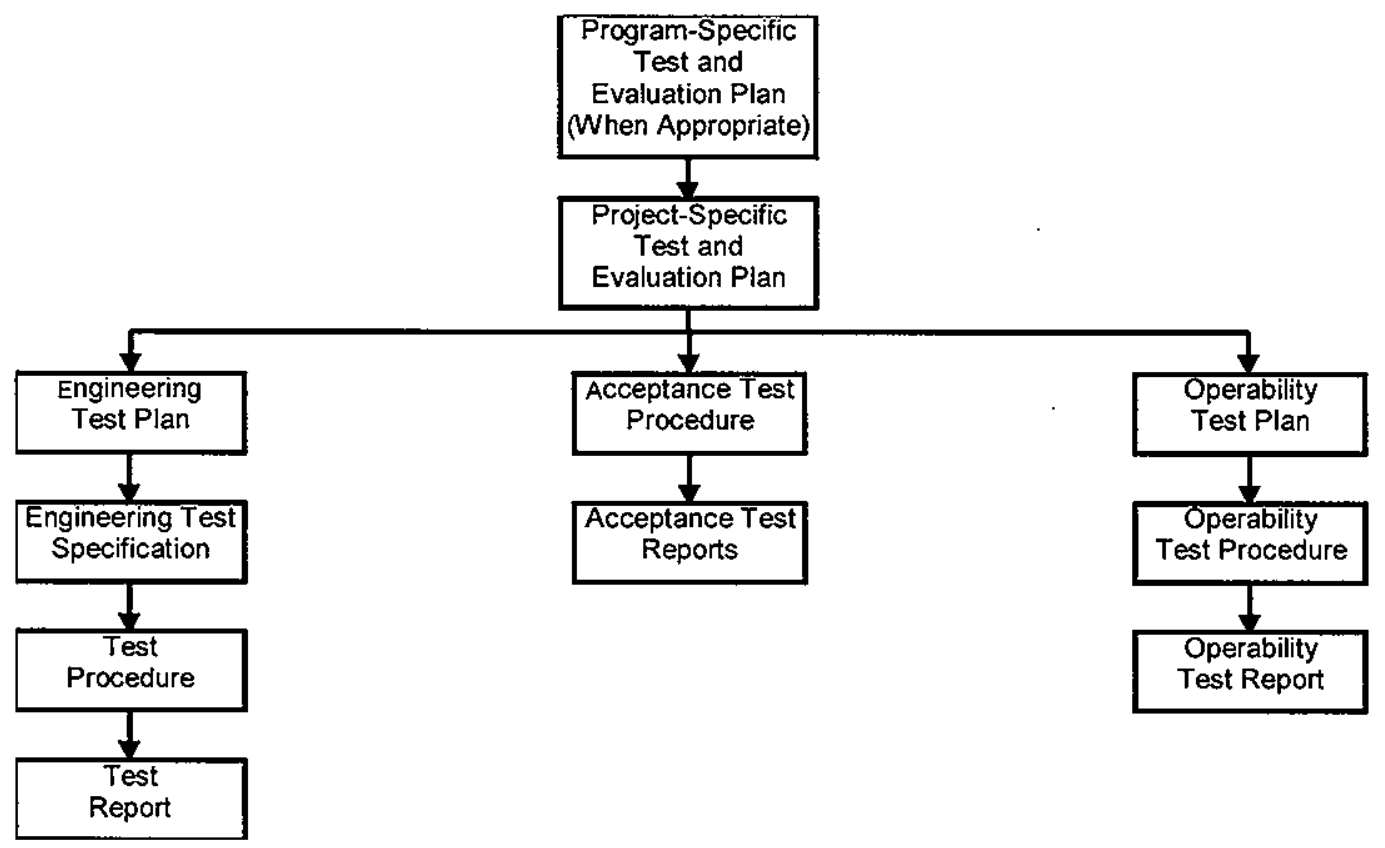

T\&E planning shall be documented in TEPs, which are prepared using this TEMP as guidance to plan, schedule, and track program, project, and operational T\&E activities. T\&E planning shall be integrated into the baseline management and control documents via established change control procedures to ensure these documents include the identified T\&E work scope, supporting budget, and schedules.

The complexity of the T\&E end product(s) should be a determining factor in the level of planning and planning documentation required. When appropriate, T\&E activities planning may be documented in the project execution plan. On projects requiring extensive T\&E, a separate TEP (or several sub-tier plans) is recommended. In addition, if acceptance testing is used extensively as a verification method, a separate plan may be warranted. Acceptance testing warrants such special planning because, unlike reviews or inspections, which are in-line 
HNF-2029

Revision 1

activities, acceptance testing is generally a separately scheduled activity. These in-line verification methods are generally planned as an integral part of the design or construction activity, and the scheduling is dictated by the design and construction schedule.

The detailed planning effort shall include the preparation of procedures to document how the various $\mathrm{T} \& \mathrm{E}$ activities will be completed. Generally, responsible organizations have standard procedures for T\&E activities such as analysis, reviews, inspections, and construction verification testing. Where appropriate, use of these standard procedures is a cost-effective approach. However, it is important that the results of the verification be documented and the results assessed against the acceptance criteria.

Testing procedures are generally necessary for nonstandard tests such as unique design concept verification or acceptance testing. Such procedures shall, at a minimum, specify the test objective, and the methods for completing the test, recording the test data/results, and evaluating the results against the acceptance criteria. These procedures shall be reviewed to ensure correctness, clarity, completeness, and adherence to requirements.

\subsection{CHANGE CONTROL}

\subsubsection{Change Control Process}

T\&E activities shall be integrated into the baseline change control process (program, project, and operations) and comply with HNF-IP-0842, MD-004, "TWRS Change Control," and HNF-IP-0842, MD-14, "Integrated Planning Process and Configuration Control." Changes to engineering documents shall be governed by HNF-PRO-440, "Engineering Document Change Control Requirements".

\subsubsection{Baseline Changes Affecting Testing and Evaluation}

Proposed baseline changes shall be evaluated to estimate their effect on the TEPs. This estimate shall then be incorporated into the cost estimate for the proposed change, and approved changes incorporated into the TEP. If the change request requires redesign, the new design must be re-verified to ensure compliance with requirements. Re-verification shall be documented and traceable to the approved change request. When testing is performed to demonstrate compliance, special care should be taken to ensure the need for re-testing is examined. Where necessary, retesting shall be specified, planned, and executed, and the test results incorporated with previous test results to ensure compliance with requirements.

\subsubsection{Baseline Changes Initiated Within Testing and Evaluation}

Baseline changes can be initiated within the T\&E effort to improve the effectiveness of $T \& E$ activities or to correct a verification activity that failed the acceptance criteria. Changes that can enhance the effectiveness of the $T \& E$ effort and reduce costs are encouraged. If a proposed change affects a baseline, the change must be processed using the approved baseline 
HNF-2029

Revision 1

change control process and procedures. For proposed changes that do not impact the baselines, the need for the change can be assessed by the project/operations team and incorporated based on merit. If the proposed change is accepted, it shall be incorporated into the T\&E planning documentation, coordinated with the affected project/operations team discipline, and implemented.

Changes initiated because of failure of a project component, subsystem, or system (including facilities) to meet the acceptance criteria must be evaluated and corrective actions undertaken by the affected project discipline as directed by management.

\subsection{TECHNICAL PERFORMANCE MEASURES}

Technical performance measures (TPM) shall be used within RPP T\&E planning activities to assess (measure) the evolving capability of the program- and project-level technical baselines to meet the established F\&Rs and accomplish the mission. The TPM process is an integral part of verifying the value of selected critical performance parameters. The RPP procedure for selecting appropriate TPMs and measuring and evaluating technical performance results is HNF-IP-0842, Volume IV, Section 2.4, "Technical Performance Measurements."

\subsection{TEST ACCEPTANCE CRITERIA}

When the performance requirements have been established, acceptance criteria shall be developed (at the appropriate time) to provide a performance measure for objectively verifying that the performance requirements have been satisfied. Acceptance criteria must be measurable, quantifiable, complete, current, accurate, and traceable. Acceptance criteria are the measures which demonstrate that the item under test meets its performance requirements. Acceptance criteria parameters or measures and tolerance bands shall be clearly established, documented, accepted, and approved. The following sections discuss acceptance criteria principles.

\subsubsection{Acceptance Criteria Measurability}

Acceptance criteria needs to be applicable to the situation (i.e. the requirement being tested and envisioned test(s)) such that the T/E methods selected should produce results that demonstrate that the acceptance criteria is satisfied. When acceptance criteria parameters that are physically measurable within reasonable project cost and schedule constraints cannot be established, the associated requirement should be questioned as to whether it is appropriate. Requirements that cannot be verified through objective measurement should not be used.

\subsubsection{Quantification}

Acceptance criteria measures and tolerance bands shall be quantitative. U.S. Department of Energy (DOE), national, or international standards that are expressed in terms such as "good" or "acceptable" must be translated into measurable, qualitative criteria. 
HNF-2029

Revision 1

\subsubsection{Completeness}

The set of acceptance criteria (i.e., measures) for each specific requirement must be complete. This principle closely relates to the consistency and traceability principles. The set of acceptance criteria for each level of test shall be established such that if the complete set is met, there is reasonable assurance that the end product(s) satisfy the customer's requirements.

\subsubsection{Currency and Accuracy}

Change control methodology shall be used to ensure that acceptance criteria are current and accurate and that, if project (or test) requirements are changed, the acceptance criteria will be changed.

\subsubsection{Consistency and Traceability}

System and technical acceptance criteria shall use the same measures (where appropriate) to define similar parameters. Acceptance criteria also shall be traceable to the requirement so the completeness of the acceptance criteria can be ensured.

\subsubsection{Acceptance Criteria Approval}

Existing approval procedures should be used to ensure proper approval for the initial acceptance criteria and any subsequent changes. Final acceptance is accomplished before operation.

\subsection{VERIFICATION}

Once acceptance criteria and requirements have been established, specific T\&E verification activities (i.e., testing) can be planned in conjunction with the program's, project's and/or facility's general planning efforts. Correct selection of a verification method helps ensure that end product(s) architecture remains in compliance with requirements as the project evolves. T\&E planning shall include appropriate turnover testing at the end of the execution phase in addition to verification conducted during the earlier phases (Requirements and Design Baseline) to demonstrate and document compliance.

The project T\&E effort concludes with turnover at the end of the Design Baseline phase. The complete set of verification results shall be reviewed and evaluated against performance requirements to ensure the results demonstrate compliance as part of the turnover activities. The project team must address and resolve any issues noted during this assessment. This evaluation and any actions required by the assessment should be documented. On complex projects, this may be a T\&E assessment report. This report should consolidate the TEPs, the T\&E activities 
HNF-2029

Revision 1

summary, testing results, and a discussion of how $\mathrm{T} \& \mathrm{E}$ activities demonstrate that the end product(s) comply with the requirements.

\subsubsection{Testing Independence}

Qualified people, other than those who designed, who will approve the design, or who will use the design, shall verify the adequacy of the design. An organization that is independent of the construction organization shall perform acceptance inspection of construction, as discussed in HNF-PRO-1819, PHMC Engineering Requirements.

\subsubsection{Verification Methods}

Verification methods are used at various stages of a project or operational life cycle to provide data for critical decisions and resolution of technical or operational issues. When acceptance criteria and performance requirements have been established, specific T\&E verification methods shall be selected and $T \& E$ activities planned and scheduled. Selection of the most appropriate T\&E method or methods and verification/acceptance criteria for a given performance requirement should be based on the following considerations:

- The method that can be applied as early as possible in the project life-cycle phase

- The method or combination of methods most appropriate to the situation

- The method that is representative and repeatable

- The method that most effectively reduces risk.

\subsubsection{Development and Design Verification}

Developmental verification methods selected during the Requirements Baseline and Design Baseline phases can include, but are not limited to, the following:

- Modeling, analysis, and calculations

- Proof-of-principal testing for new technologies

- Reviews, alternative calculations and qualification testing

- Laboratory process testing, prototype, and mockup equipment testing

- Quality Assurance audits, Quality Control inspections, and in-process inspections

- Vendor qualification testing, equipment qualification tests, and acceptance test procedures (ATP) 
HNF-2029

Revision 1

- Operational test procedures (OTP), test reports, ATPs, and post-installation and preoperational acceptance tests

- Integrated system operational testing.

\subsubsection{Operational Verification}

Operational verification methods can include the following:

- Mockup testing under simulated field conditions

- Post-installation acceptance tests, integrated cold or hot testing

- Surveillance, functional testing, periodic inspection, process tests

- Post-maintenance testing, preventive maintenance performed during operations

- Surveillance and preventive maintenance performed after deactivation.

\subsubsection{Integration of Verification Results}

T\&E documentation shall provide traceability among the performance requirements, $T \& E$ activities, and $T \& E$ results to demonstrate that the project end product(s) meet acceptance criteria. The complete set of testing results shall be reviewed against performance requirements as part of the turnover process for projects and before any readiness review activities.

Testing results also shall be evaluated against other testing activities and results to ensure that problems and unacceptable and/or unexpected results encountered in one series of tests do not impact other testing and verification activities. If testing (verification) activity results do not comply with requirements, the results must be reassessed as early as possible to identify alternative approaches for meeting requirements with a minimum impact on resources, risk, and baseline activities. Alternative approaches, which require a change to the baseline or requirements, need to be implemented through the established change control process.

\subsubsection{System Verification}

System verification testing is required to demonstrate that the system will satisfy the system-level functions and performance requirements. System T\&E planning should include input from engineering specialties to define an effective and economical total system testing approach that takes into account the following objectives.

- Whenever practical, testing for different objectives should be combined. 
HNF-2029

Revision 1

- Verification of the acceptability and compatibility of human performance requirements, training, and person-machine interfaces shall be integrated into system testing.

- System testing should be accomplished in a well-defined sequence.

Several levels of system testing may exist. For example, system testing could be initiated at the component level, and then progress to the subsystem, segment, and system levels. Such a sequence for an acceptance test program might include installation checks, leak tests, system operational testing with minimum parameters, system operation with normal parameters, and operational modes.

\subsection{TESTING AND EVALUATION FOR REQUIREMENTS BASELINE PHASE}

T\&E efforts during the Requirements Baseline phase (pre-conceptual activities) focus on the following general topics:

- Identifying and documenting T\&E performance requirements

- Documenting identified risks

- Initial planning required for $T \& E$ work activities

- Verifying that proposed technologies (or new processing operating scenarios) and upper-level architecture will satisfy the top-level functions and performance requirements.

This includes T\&E activities needed to determine if new or modified facilities or systems are needed. A program-level TEP shall be prepared (where appropriate) to formally evaluate and document the development testing and analyses required (based on risk levels) to prove requirement need and necessary capability levels. Other T\&E efforts during the Requirements Baseline phase include the following:

- Establishing verification approach/strategy

- Identifying verification efforts and products

- Establishing a TPM program

- Identifying critical issues to test their integration with planning efforts.

\subsubsection{Early Prototype Testing}

A graded approach shall be employed when deciding which designs and requirements require development testing. Enabling assumptions and new technologies (and processing operations) shall be proven at the first opportunity. Early prototype and proof-of-principal testing during the Requirements Baseline phase does not require that the equipment be tested under the anticipated operational environmental conditions. Testing may require that only the 
HNF-2029

Revision 1

functional concept be tested. The results of these evaluations demonstrate if the process and equipment will repeatedly accomplish the desired result.

\subsubsection{Early Prototype Testing Documentation}

Development testing to prove process/architecture design concepts shall be traceable to test procedures, test documents, and reports that document the evaluation of results. Adequate documentation shall be maintained to provide a basis for the technology and/or architecture selection.

\subsection{TESTING AND EVALUATION FOR DESIGN BASELINE PHASE}

The Design Baseline phase further develops the project $F \& R$ defined during the requirements baseline development activities. Developmental and operational verification testing continues through this phase to further refine process parameters and to evaluate and select specific architecture elements. At the start of the conceptual design effort, the acceptance criteria are defined for each requirement documented in the project specifications. The test method(s) to be used to verify requirements are then selected with the intent to verify high-risk requirements as early in the life cycle as is reasonably possible. As the performance requirements and acceptance criteria mature, the project architecture is modified and adapted to meet these new or revised performance requirements and acceptance criteria. The TEP is modified to incorporate changes to the project architecture and performance requirements or acceptance criteria.

Design concepts involving new technology or unverified requirements may require some level of engineering (proof-of-concept) testing. Some design concepts involving proven technologies also may require some level of development testing to verify that the concepts can satisfy specific performance requirements. Proof-of-concept tests and/or simulations are essential in limiting the project risks by verifying that the process and general architecture proposed will satisfy performance requirements.

\subsubsection{Development Testing}

Development testing is used in the Design Baseline phase to refine the original design, and to select the detailed architecture elements (physical components) and the relationship between these components. Early in the Design Baseline phase, this process may involve smallscale testing of prototypical equipment. Full-scale mockups, with build-to-specification equipment, are used later in the Design Baseline phase to be tested and/or evaluated under simulated operating conditions. If any of the acceptance criteria are not met at this point, modifications to the design must be incorporated and re-verified. Where development testing cannot be performed because of cost or schedule considerations, or because of an inability to replicate the actual field conditions, the design must be validated and documented through analysis, simulations, and design reviews. 
HNF-2029

Revision 1

\subsubsection{Reviews}

Reviews shall be used to determine design performance and conformance with specified requirements and acceptance criteria by examination of items such as engineering drawings, analysis results, calculations, flow diagrams, specifications, and computer programs.

Verification reviews (as identified in HNF-SD-WM-SEMP-002 or peer reviews) are also performed to ensure correctness, completeness, and compliance with technical requirements. The review of design output should be a continuing activity throughout the design. Formal periodic design reviews shall be conducted throughout the design process. Results of these reviews shall be evaluated and acted upon in accordance with approved processes and procedures.

\subsubsection{Analysis}

Analysis can be used to predict performance where testing under design conditions is not possible. In this case, the performance requirements for structural loading are verified by stress calculations concurrently in the design process to ensure that the design specifications will meet strength requirements. Subsystems and components may be tested to design loads or to failure to validate analysis and modeling tools. Other analyses can include, but are not limited to, safety analyses, chemical mixing/treatment calculations, thermal-hydraulic calculations, mass and energy balance calculations, seismic analyses, and electrical breaker coordination studies.

\subsubsection{Operational Testing and Evaluation Plan}

Early in the Detailed Design phase, the project shall prepare, where appropriate, an operational-focused TEP (a subset of the TEP). This TEP shall (1) define remaining verification activities required in the pre-operational and operational acceptance testing phases; and (2) identify verification products, activities, and the logic sequence that will govern their implementation. The project TEP provides an overall integration of the products identified in the operational TEP. This information shall be incorporated into the baseline control documents.

Examples of T\&E products identified in the operational TEP include the following:

- ATPs

- Test procedures used for design analysis, verification, vendor testing, mockup testing, calibration, grooming, alignment, etc.

- Test specifications

- T\&E products needed for operational readiness and readiness assessment reviews

- OTPs

- System acceptance tests. 
HNF-2029

Revision 1

Test-specific procedures shall be developed early in the Detailed Design subphase. In addition, specific acceptance criteria and test measurement parameters shall be established and incorporated into the test procedures as early as possible.

\subsubsection{Procurement Testing}

Acceptance testing should be used to confirm that equipment being procured meets the acceptance criteria under simulated operational environmental conditions with a margin of safety. These tests are recommended whenever equipment is used in a new application or in severe environments. Qualification testing shall be conducted at levels that exceed required performance. Qualification test planning should cover all stages of equipment assembly (as appropriate), handling, shipping, receiving, and storage.

When an equipment manufacturer/vendor is selected to supply a component or subsystem, the performance and testing requirements shall be identified in the procurement specification and associated contract(s). The vendor is responsible for ensuring the equipment meets the requirements. Before testing, the vendor should be required to submit test/evaluation procedures to the buyer for review and approval. Before delivery and acceptance, the vendor shall be required to submit test results and documentation to the buyer for review and acceptance.

In cases where the consequences of failure are costly or dangerous, the buyer may require the manufacturer/vendor to conduct mockup tests. The purpose of these tests is to fully demonstrate the ability of the equipment to perform the required design functions and meet the associated performance requirements.

\subsubsection{Construction}

The execution phase of a project encompasses the construction (fabrication, procurement, and installation) and turnover activities or subphases. Vendor-provided equipment is subjected to appropriate Quality Assurance and Quality Control inspections and testing. Installed equipment is subject to appropriate in-process inspections, calibrations, alignment, and postinstallation acceptance and operational testing. Before the planned operational startup date of a system, operating procedures are validated and the entire system tested, if appropriate, in an integrated cold and/or hot test.

Quality control and in-process inspections are used to verify critical tolerances, installation methods, etc., that cannot be adequately tested after the equipment has been installed. Verification methods used include physical measurements, visual observation and. documentation, radiography, ultrasonic tests, dye penetrant, and other nondestructive examination methods.

Calibration, grooming, and alignment activities are required to ensure that installed equipment has been properly prepared for acceptance testing. Interaction of the component/system with other components/systems should be considered when planning 
HNF-2029

Revision 1

calibration, grooming, and alignment activities. For example, before testing a pump, instrumentation should be calibrated, electrical continuity and motor phase rotation should be checked, and motor-to-pump alignment should be completed.

Construction planning shall be included in the appropriate TEP to address installation of test items and test equipment and to ensure the presence of test personnel in the construction area who support testing requirements. Close planning and implementation coordination between construction and testing personnel will ensure worker safety and successful completion of scheduled tests.

\subsubsection{Post-Installation and Pre-Operational Acceptance Testing}

The purpose of acceptance testing is to prove that installed components meet specified system-level performance requirements. Duplicate testing to verify the same requirements shall be eliminated.

The project uses acceptance and pre-operational tests to verify that systems delivered meet the agreed upon performance requirements. It is essential that the responsible RPP enduser organization verify that the ATP scope is comprehensive, the test conditions are realistic, and the acceptance criteria are clearly stated in the operational TEP.

Acceptance test reports, including a record copy of the completed ATP, test deficiencies/resolutions, and records of repairs/modifications and re-testing performed, shall be required. Final acceptance test reports shall be submitted to the RPP end-user organization before the system(s) are accepted for operation.

The requirements for accepting systems for operation (including operational readiness and readiness assessment reviews) are described in HNF-IP-0842, Section 3.12, "Acceptance of Structures, Systems, and Components for Beneficial Use."

\subsubsection{Integrated Operational Testing}

Integrated system operational tests verify that all subsystems and systems work as an integrated unit. Integrated operational testing may be required on several different levels, addressing systems and subsystems individually, then addressing the larger and allencompassing parent system or facility. The integrated operational test(s) verifies system interfaces and overall system/facility performance under actual operating conditions. Integrated system tests verify that the entire system meets the critical operational performance requirements for the integrated system (e.g., throughput, overall processing rate, processing efficiency, etc.) in all operational environments, including analyzed emergencies or off-normal events. 
HNF-2029

Revision 1

At the conclusion of the integrated operational testing, a design and operations team shall review the project and operational TEPs to verify that required testing has been completed for each performance requirement, and that it is traceable to an analysis, calculation record, inspection report, test procedure/report, etc. This review of the TEP(s) and supporting T\&E documents shall be used as input to the readiness review process (if an operational readiness review is part of the specific project scope).

\subsubsection{Operational Testing at Turnover}

As part of the turnover process (including the acceptance for beneficial use and operational readiness review processes), the RPP end-user organization shall review the project documentation submitted as evidence that the physical system(s) and supporting infrastructure will operate properly and meet performance requirements. These reviews can be limited in scope or highly detailed, as in the case of operational readiness and readiness assessment review activities.

The end-user organization has the responsibility to verify that the system(s) and infrastructure elements are adequate by performing work in accordance with the OTPs and reviewing documentation. The OTPs provide an essential opportunity to complete on-the-job training or other in-field operator qualification requirements. The OTPs verify the following.

- The system(s) operate as expected in operational environments, including analyzed emergencies or off-normal events.

- The equipment is properly labeled and configured as shown in the procedures and drawings.

- Components required to be operated are accessible and free of obstructions or binding.

- Installed instrumentation responds to changing conditions in all operational environments, including analyzed emergencies or off-normal events.

After completion of the end-user verification process and the correction of deficiencies as directed by the end-user organization and approved procedures, the systems can be accepted for operation. After each individual system has been accepted through the ATP and OTP process and the supporting infrastructure elements required for operation have been verified, an integrated test shall be conducted (where appropriate).

\subsection{TESTING AND EVALUATION FOR OPERATIONS BASELINE PHASE}

Testing activities implemented during the operational phase focus on supporting each operation mission. Tests are specific to each facility and shall be planned, managed, reviewed, and accepted by qualified staff at the facility. The following sections discuss testing topics that are commonly encountered during the operational phase. Facility-specific T\&E management 
HNF-2029

Revision 1

shall ensure that staff use appropriate approved test procedures and documentation (see the references in Section 6.0 for test activities).

\subsubsection{Operations and Maintenance Testing and Evaluation}

Before startup (during the Design Baseline phase and documented in the operational TEP), an ongoing program of periodic surveillance testing and post-maintenance testing must be developed and instituted to ensure the equipment can continue to perform its design function. The program shall be fully implemented and verified during the Operations Baseline phase.

\subsubsection{Surveillance Testing}

Surveillance testing is performed to periodically verify the operability of systems specifically required to be operable by TSRs. Surveillance testing may be an operations or a maintenance task, depending on the nature of the action required to perform the test or inspections. Equipment that meets the acceptance criteria can be considered operable. Equipment that fails to meet the acceptance criteria is declared inoperable, and the TSR action statements are invoked where appropriate.

\subsubsection{Functional Testing}

Functional testing is a method for verifying that a system can perform its intended function(s) by actual operation of the system and evaluation of performance parameters under conditions similar to those expected under worst-case, normal, and emergency modes. Functional tests are generally performed to satisfy surveillance test requirements specified in the TSRs. For RPP facilities, most of the safety systems required by the TSRs are associated with passive functions for monitoring. Functional testing for an instrument verifies that for a given input, the channel or loop generates an output signal that is within the expected range for the specific input condition. This verifies the proper operation of the entire instrument loop without testing every component inside the loop or instrument channel.

\subsubsection{Preventive Maintenance}

Periodic preventive maintenance may be required by the surveillance test program or to satisfy engineering or vendor recommendations. Preventive maintenance may be as simple as checking a pump seal to ensure the proper leak-off rate, or as complex as a complete disassembly of a pump to inspect the impeller and seal condition. Regardless of the complexity or nature of the preventive maintenance, data collected should be recorded and reviewed for trending purposes and to aid in predictive maintenance. 
HNF-2029

Revision 1

\subsubsection{Post-Maintenance Testing}

After a component is replaced or repaired, a test should be performed to ensure that after the component or system is returned to service, it again can perform its design function. For systems that provide a safety function, a functional test is typically performed to verify operability.

A graded approach should be applied to post-maintenance testing. For example, if a pump is taken out of service for shaft seal replacement, an appropriate test may simply involve starting the pump and verifying that the pump rotates in the proper direction and seal leak-off is adequate. However, if a pump is taken out of service for impeller replacement, a system functional test should be performed to verify proper pump discharge pressure, flow, pump speed and amperage, etc. Further information and guidance on this subject are in HNF-IP-0842, Volume V, Section 7.2, "Post-Maintenance Testing."

\subsubsection{Production/Process Testing}

Production/process testing is performed at operating facilities. The testing generally consists of making a controlled change in a production or processing operation to evaluate potential improvements, develop optimum process parameters, or establish new criteria. HNF-IP-0842, Volume IV, Section 4.8, "Process Control Plans," provides requirements for this type of testing.

\subsubsection{Major Facility/Operational Modifications Testing and Evaluation}

T\&E planning shall be performed for major operational activities that will use installed equipment that has not been subject to a periodic surveillance testing and preventive maintenance program or that has not been demonstrated previously. Periodic surveillance testing (e.g., functional tests, calibration or loop checks, etc.) can verify that existing systems perform at routinely demonstrated levels: Separate component or system-level tests or inspections may be required to verify performance requirements that are not routinely demonstrated. Integrated system testing also may be required to fully verify system interfaces and overall operational performance of a system or multi-system configuration.

\subsubsection{Closeout Testing and Evaluation}

When a facility has completed its operating mission, it enters the closeout phase of its program life cycle. T\&E activities in this phase focus on the following issues:

- Maintaining the safety of the public and the facility personnel when a facility is in a shutdown mode

- Ensuring the goals and objectives of the D\&D plan are fulfilled. 
HNF-2029

Revision 1

The first part of the closeout phase is deactivation. When a facility is deactivated, the nature of the associated risks changes. Initially, these risks are dictated by the operating history of the facility. During deactivation, the radioactive or hazardous material inventory is eliminated or reduced to the extent possible without dismantling the facility systems or structures. The inventory that cannot be readily removed is stabilized and/or contained to minimize the potential for release before final D\&D. After deactivation, the facility enters a "limited surveillance and maintenance" phase. The facility may stay in this state for an extended period until D\&D activities begin.

During the deactivation planning stage of a project or facility, a revised surveillance and maintenance plan shall be developed consistent with the revised TSRs. Surveillance and maintenance in the post-deactivation phase are directed toward ensuring that the remaining hazardous and radioactive materials are contained and monitored. Preventive maintenance is performed only as required to preserve any remaining safety systems or to prevent substantial degradation of systems essential to D\&D.

Corrective maintenance tasks are only performed in the limited surveillance and maintenance phase to repair safety systems (if any) and systems necessary for monitoring functions. Limited repairs may be performed to prevent substantial degradation of assets that may have future use. All other corrective maintenance should be discontinued.

\subsection{TESTING AND EVALUATION PLANS}

$T \& E$ activities are implemented as specified by program-, project-, and facility-specific TEPs. All RPP programs, projects, and facilities/operations shall generate TEPs to identify required T\&E activities. Appendix B presents the minimum required content for TEPs. Subsections of Appendix B can be tailored address specific situations.

The program, project, and operational TEP shall address each requirement (as appropriate), the verification methods to be used, acceptance criteria used to demonstrate compliance, the performance period for the activities, and the estimated cost if the activity is estimated separately from other project activities. The TEP also should identify significant resources to conduct verification and reporting activities. Significant resources include identifying needed facilities, equipment, skills, and other items needed to conduct the verification activities. If testing activities are extensive, a separate plan (or sub-tiered plans) may be warranted and used.

\subsection{ISSUES AND RISKS TO BE ADDRESSED BY TESTING AND EVALUATION PLANS}

The TEP provides a balance between risk and cost/schedule impacts. Functions and associated performance requirements that involve new technology or untested processes or equipment configurations may have to be tested several times throughout the life cycle of the project/program to validate that critical results observed are repetitive. 
HNF-2029

Revision 1

T\&E planning considers various combinations of verification methods and the extent of testing necessary to provide confidence that the technologies and design concepts will perform as required. T\&E planning also verifies that the final design and as-installed or delivered systems actually do perform as required. The project TEP(s) shall ensure that each performance requirement is verified at the appropriate phase of the project/program to minimize the technical and operational risks.

Critical requirements are those functions the system must perform in order to achieve mission accomplishment. Critical issues are the subset of these critical requirements that are judged to be at risk and requiring $T \& E$ activities to mitigate the risk. Critical issues are also those aspects of a system's capability (operational, technical, or other) that must be determined before the overall effectiveness of a system can be determined. These issues could include areas of risk in the design, development, installation, and operation of a system.

\subsection{RIVER PROTECTION PROJECT TESTING AND EVALUATION IMPLEMENTING PROCEDURES}

This section provides a brief overview of existing procedures that implement $T \& E$ within RPP. This list will be updated as needed, but the reader is advised to verify that all appropriate procedures are reviewed and complied with for each specific situation.

\subsection{HNF-IP-0842, TWRS ADMINISTRATIVE MANUAL, TESTING AND EVALUATION-RELATED PROCEDURES}

The following sections are based on HNF-IP-0842, TWRS Administrative Manual.

\subsubsection{Volume 4, Section 2.12, "Testing and Evaluation"}

This procedure requires that all RPP program, project, and facility organizations implement the T\&E products and processes identified in the TEP. The TEP is a RPP systems engineering product that is specified in this TEMP. Implementation of the TEP ensures that the necessary level of T\&E activities are identified and incorporated in baseline work authorization documentation.

\subsubsection{Volume I, Section 1.1, "Winterization Plan for 200 Area Tank Farms"}

This procedure defines the responsibilities and requirements for implementation, surveillance, analysis, and assessment of the RPP cold-weather protection program in accordance with HNF-PRO-472, Cold Weather Protection (also includes equipment testing requirements). 
HNF-2029

Revision 1

\subsubsection{Volume 1, Section 1.3, "Integration of Operational Readiness and Readiness Assessment Review Planning in the Project Life Cycle"}

This procedure provides early planning guidance and direction to programs or projects that will conduct operational readiness or readiness assessment reviews. Projects that are not subject to operational readiness or readiness assessment reviews are encouraged to use this procedure as appropriate.

The objective of this procedure is to mandate early planning actions within a program or project to identify actions and products which, when implemented during the DOE standard project life cycle (and as defined in HNF-SD-WM-SEMP-002 [Peck 1998]), will ensure that operational readiness and readiness assessment reviews are successfully completed. The actions and/or products are incorporated into the project baseline scope to ensure that the program, project, and facility can demonstrate that it complies with the set of core requirements in DOE O 425.1A, Startup and Restart of Nuclear Facilities, Section 4d (DOE 1998), during future operational readiness and readiness assessment reviews.

These core requirements are the basis for operational readiness and readiness assessment reviews. Identifying how the core requirements apply to the program or project and the products necessary to demonstrate compliance with them early in the life cycle ensures that the project will successfully complete the future operational readiness and readiness assessment reviews.

\subsubsection{Volume II, Section 4.1.3, "Joint Test Review Process"}

This procedure defines a process that involves people with diverse backgrounds and experience to provide a more mature and synergistic review of SSC testing or work activities within RPP. This review will result in safer testing and ensure SSCs meet test procedure specifications. This procedure identifies responsibilities and requirements for the use of a Joint Test Review Group in RPP.

This procedure primarily applies to SSCs at RPP that undergo modification, upgrading, or new construction. The typical testing categories covered are acceptance testing, qualification testing, pre-operational testing, and operational testing. The project/facility manager can use the added rigor of this procedure on any activity.

\subsubsection{Volume IV, Section 3.12, “Acceptance of Structures, Systems, and Components for Beneficial Use"}

This procedure identifies responsibilities and requirements to ensure the end users of new SSCs and modifications and upgrades to existing SSCs have all the necessary documentation to operate and maintain the supplier-provided SSCs. 
HNF-2029

Revision 1

\subsubsection{Volume 4, Section 4.24, "Design Verification"}

This procedure establishes the requirements governing design verification measures established to verify the adequacy of the design (both final design and subsequent changes/revisions) for the intended applications.

\subsubsection{Volume 4, Section 4.6, "Functional Tests"}

This procedure establishes the requirements and responsibilities for functional testing to ensure equipment maintenance work is completed satisfactorily before the equipment is returned to service. This procedure applies to repair, periodic work, and minor configuration changes to all RPP facilities. The changes are to be of such simple size, complexity, and technical risk that the changes do not warrant use of formal test execution, test reviews, and test documentation required by formal acceptance and operability tests.

\subsubsection{Volume 4, Section 4.7, "Process Tests"}

This procedure defines the requirements for process tests, including the preparation of process test plans, process test procedures, process test readiness reviews, and process test evaluation reports by RPP programs. This procedure applies only to process tests scheduled and performed at RPP facilities or programs. It does not apply to minor modifications, pilot-plant tests, tests of prototype process equipment outside an operating plant, and operability tests of new process systems with nonradioactive materials.

\subsubsection{Volume 4, Section 4.28, "Testing Practices Requirements"}

This procedure establishes the general requirements for testing activities conducted by or for RPP on RPP-managed SSCs and computer software. This procedure does not apply to American Society of Mechanical Engineers in-service inspection programs, nondestructive examinations, routine maintenance testing, routine system compliance or functional testing, or routine radiation or other environmental/surveillance activities.

\subsubsection{Volume IV, Section 2.3, "Design Authority Process, Selection, and Responsibilities"}

This procedure establishes the process, relationships, and selection requirements for RPP design authority and engineering discipline expert assignments and defines associated responsibilities.

\subsubsection{MD-004, "Tank Waste Remediation System Change Control"}

This management directive applies to each organization managing work contained within HNF-MD-017, Multi-Year Work Plan (FDH 1997). It applies to all changes affecting the 
HNF-2029

Revision 1

technical, work scope, schedule, and/or cast baseline elements contained within the Multi-Year Work Plan.

\subsubsection{MD-14, "Integrated Planning Process and Configuration Control"}

This management directive establishes the use of the integrated planning process as the method to define technical scope, cost, and schedule for work scope in proposals, estimates and budgets affecting the TWRS Project. This directive also addresses central control and configuration management of the technical basis review planning packages developed or revised during the integrated planning process.

\subsection{PROJECT HANFORD MANAGEMENT CONTRACT - HNF-PRO SERIES TESTING AND EVALUATION-RELATED PROCEDURES}

\subsubsection{HNF-PRO-1819, PHMC Engineering Requirements}

This procedure establishes requirements for the practice of engineering to be used by Fluor Daniel Hanford, Inc. (FDH) and the Project Hanford Management Contract (PHMC) major subcontractors, including DynCorp Tri-Cities Services, Inc. These requirements have been arranged according to their application within a typical engineering process. The requirements account for applications at all life-cycle stages of an SSC. Some requirements have been graded to account for an SSC being deactivated. The grading of a requirement is listed with the requirement to which it applies.

The basis for this procedure is that each PHMC major project (RPP, Spent Nuclear Fuel, Infrastructure, Facility Stabilization, and Waste Management) will establish design baselines for its SSCs and designate design authorities responsible for the design baselines.

\subsubsection{HNF-PRO-1997, Construction Program Overview}

This procedure provides an overview of the scope, responsibilities, and procedural structure for the Construction Program topical area. Construction Program procedures cover all construction activity performed under the PHMC. As used in the Project Hanford Management System, "construction activity" means any combination of engineering, procurement, erection, installation, assembly, demolition, or fabrication modifying, creating, or eliminating a physical structure (or facility) or system. Modifying includes altering, adding to, or rehabilitation beyond routine maintenance (i.e., like-for-like replacement) and where other than minor/incidental design revision is required. Construction activity includes not only formal DOE construction projects (line items and general plant projects) but also facility modification activities, regardless of the funding type (capital, operating, expense, or capital equipment not related to construction). 
HNF-2029

Revision 1

\subsubsection{HNF-PRO-1998, Construction Program Pre-Conceptual Activity}

This procedure provides guidance for all pre-conceptual construction activity performed under the PHMC. It is one of a series of Construction Program procedures. Construction Program procedures are arranged to correspond to the three major phases of a typical construction activity (pre-conceptual, conceptual, and execution) as shown in Figure 1 of HNF-PRO-1997, Construction Program Overview. This pre-conceptual procedure applies not only to formal construction projects (i.e., general plant projects, line item projects and above, and other construction activity specifically designated by FDH Project Direction) but also to minor construction activity (i.e., construction activity that does not meet the definition of a formal construction project). Section 1.1 of HNF-PRO-1997 provides an additional discussion of construction activity.

\subsubsection{HNF-PRO-1999, Construction Program Conceptual Phase}

This procedure provides guidance for all Construction Program conceptual phase activity performed under the PHMC. It is one of a series of Construction Program procedures. Construction Program procedures are arranged to correspond to the three major phases of a typical construction activity (Pre-Conceptual, Conceptual, and Execution) as shown in Figure 1 of HNF-PRO-1997, Construction Program Overview.

This conceptual procedure applies not only to formal construction projects (i.e., general plant projects, line item projects and above, and other construction activity specifically designated by FDH Project Direction) but also to minor construction activity (i.e., construction activity that does not meet the definition of a formal construction project). Section 1.1 of HNF-PRO-1997 provides an additional discussion of construction activity. Section 3.1 .1 of HNF-PRO-1998, Construction Program Pre-Conceptual Activity, provides information on formal construction projects and minor construction activity.

\subsubsection{HNF-PRO-097, Engineering Design and Evaluation}

This procedure defines the minimum criteria for structural design and evaluation of SSCs. The structural design loads and structural acceptance criteria are established for use to design new SSCs, evaluate existing SSCs, evaluate anchorage effects of new and modified systems on existing SSCs, and design additions and modifications to existing SSCs. For convenience, this procedure includes pertinent requirements from DOE Order 6430.1A, General Design Criteria (DOE 1989); DOE O 420.1, Facility Safety (DOE 1995); and DOE-STD-1020-94, Natural Phenomena Hazard Design and Evaluation Criteria for Department of Energy Facilities (DOE 1994). This procedure does not supersede the two DOE Orders, and requirements in the DOE Orders govern if inconsistencies occur. 
HNF-2029

Revision 1

\subsection{REFERENCES}

DOE, 1989, General Design Criteria, DOE Order 6430.1A, U.S. Department of Energy, Washington, D.C.

DOE, 1994, Natural Phenomena Hazard Design and Evaluation Criteria for Department of Energy Facilities, DOE-STD-1020-94, U.S. Department of Energy, Washington, D.C.

DOE, 1995, Facility Safety, DOE Order 420.1, U.S. Department of Energy, Washington, D.C.

DOE, 1998, Startup and Restart of Nuclear Facilities, DOE O 425.1A, U.S. Department of Energy, Washington, D.C.

FDH, 1997, Multi-Year Work Plan, HNF-MD-017, Rev. 0, Fluor Daniel Hanford, Inc., Richland, Washington.

Gibson, E. R., 1998, TWRS Administrative Manual, HNF-IP-0842, Fluor Daniel Hanford, Inc., Richland, Washington.

HNF-PRO-097, Engineering Design and Evaluation, Fluor Daniel Hanford, Inc., Richland, Washington.

HNF-PRO-472, Cold Weather Protection, Fluor Daniel Hanford, Inc., Richland, Washington.

HNF-PRO-1819, PHMC Engineering Requirements, Fluor Daniel Hanford, Inc., Richland, Washington.

HNF-PRO-1997, Construction Program Overview, Fluor Daniel Hanford, Inc., Richland, Washington.

HNF-PRO-1998, Construction Program Pre-Conceptual Activity, Fluor Daniel Hanford, Inc., Richland, Washington.

HNF-PRO-1999, Construction Program Conceptual Phase, Fluor Daniel Hanford, Inc., Richland, Washington.

Peck, L. G., 1998, Tank Waste Remediation System Systems Engineering Management Plan, HNF-SD-WM-SEMP-002, Rev. 1, prepared by Lockheed Martin Hanford Corporation for Fluor Daniel Hanford, Inc., Richland, Washington. 
HNF-2029

Revision 1

APPENDIX A

TABLE OF REQUIREMENTS FOUND IN THIS DOCUMENT

A-1 
HNF-2029

Revision 1

This page intentionally left blank.

A-2 
HNF-2029

Revision 1

Table A-1. Requirements Found in this Document (5 sheets).

\begin{tabular}{|c|c|c|}
\hline $\begin{array}{l}\text { Require- } \\
\text { ment } \\
\text { number }\end{array}$ & Section & TEMP requirement \\
\hline 1 & 1.0 & $\begin{array}{l}\text { T\&E planning, implementation, and verification activities shall be performed to } \\
\text { verify that system(s) (along with their subsystems and components) can be } \\
\text { designed, installed, and operated to satisfy their specified source requirements and } \\
\text { operational characteristics. }\end{array}$ \\
\hline 2 & 1.0 & $\begin{array}{l}\text { T\&E activities shall be conducted throughout each phase of a project's life cycle } \\
\text { and during the Operation Baseline Phase (see Figure } 1 \text { in the main text) to } \\
\text { minimize risk and provide confidence that the new or modified system(s) will } \\
\text { operate as planned. }\end{array}$ \\
\hline 3 & 3.3 & $\begin{array}{l}\text { The facility manager shall ensure that design, testing, and verification } \\
\text { independence are established in accordance with procedures. }\end{array}$ \\
\hline 4 & 3.5 & $\begin{array}{l}\text { T\&E engineering activities, responsibilities, and products shall be implemented as } \\
\text { specified in HNF-PRO-1819, PHMC Engineering Requirements, and } \\
\text { HNF-IP-0842, TWRS Administrative Manual, Volume 1, Section 3.30, "TWRS } \\
\text { Technical Operations and Engineering Charter." }\end{array}$ \\
\hline 5 & 3.6 & $\begin{array}{l}\text { The T\&E activities, responsibilities, and products required from the design } \\
\text { authority shall be implemented as specified in HNF-PRO-1819, PHMC } \\
\text { Engineering Requirements, and HNF-IP-0842, TWRS Administrative Manual, } \\
\text { Volume IV, Section 2.3, "Design Authority Roles and Responsibilities." }\end{array}$ \\
\hline 6 & 4.0 & $\begin{array}{l}\text { Along with the guidance in Section } 4.0, T \& E \text { planning and implementation } \\
\text { activities shall include the T\&E engineering requirements provided in } \\
\text { HNF-PRO-1819, PHMC Engineering Requirements. }\end{array}$ \\
\hline 7 & 4.1 & $T \& E$ activities shall be traceable to requirements. \\
\hline 8 & 4.1 & $\begin{array}{l}\text { The T\&E planning processes and identified products shall be incorporated into the } \\
\text { appropriate baseline documentation commensurate with the complexity, risk, and } \\
\text { visibility of the program, project, or operational activity. }\end{array}$ \\
\hline 9 & 4.1 & $\begin{array}{l}\text { T\&E planning shall be documented in TEPs, which are prepared using this TEMP } \\
\text { as guidance to plan, schedule, and track program, project, and operational T\&E } \\
\text { activities. }\end{array}$ \\
\hline 10 & 4.1 & $\begin{array}{l}\text { T\&E planning shall be integrated into the baseline management and control } \\
\text { documents via established change control procedures to ensure these documents } \\
\text { include the identified } T \& E \text { work scope, supporting budget, and schedules. }\end{array}$ \\
\hline 11 & 4.1 & $\begin{array}{l}\text { The detailed planning effort shall include the preparation of procedures to } \\
\text { document how the various } T \& E \text { activities will be completed. }\end{array}$ \\
\hline 12 & 4.1 & $\begin{array}{l}\text { Such procedures shall, at a minimum, specify the test objective, and the methods } \\
\text { for completing the test, recording the test data/results, and evaluating the results } \\
\text { against the acceptance criteria. }\end{array}$ \\
\hline 13 & 4.1 & $\begin{array}{l}\text { These procedures shall be reviewed to ensure correctness, clarity, completeness, } \\
\text { and adherence to requirements. }\end{array}$ \\
\hline 14 & 4.2 .1 & $\begin{array}{l}\text { T\&E activities shall be integrated into the baseline change control process } \\
\text { (program, project, and operations) and comply with HNF-IP-0842, TWRS } \\
\text { Administrative Manual, MD-004, "TWRS Change Control," and HNF-IP-0842, } \\
\text { MD-14, "Integrated Planning Process and Configuration Control." }\end{array}$ \\
\hline 15 & 4.2 .2 & Proposed baseline changes shall be evaluated to estimate their effect on the TEPs. \\
\hline 16 & 4.2 .2 & $\begin{array}{l}\text { If the change request requires redesign, the new design must be re-verified to } \\
\text { ensure compliance with requirements. }\end{array}$ \\
\hline
\end{tabular}


Table A-1. Requirements Found in this Document (5 sheets).

\begin{tabular}{|c|c|c|}
\hline $\begin{array}{l}\text { Require- } \\
\text { ment } \\
\text { number }\end{array}$ & Section & TEMP requirement \\
\hline 17 & 4.2 .2 & $\begin{array}{l}\text { Where necessary, re-testing shall be specified, planned, and executed, and the test } \\
\text { results incorporated with previous test results to ensure compliance with } \\
\text { requirements. }\end{array}$ \\
\hline 18 & 4.2 .3 & $\begin{array}{l}\text { If a proposed change affects a baseline, the change must be processed using the } \\
\text { approved baseline change control process and procedures. }\end{array}$ \\
\hline 19 & 4.2 .3 & $\begin{array}{l}\text { If the proposed change is accepted, it shall be incorporated into the T\&E planning } \\
\text { documentation, coordinated with the affected project/operations team discipline, } \\
\text { and implemented. }\end{array}$ \\
\hline 20 & 4.2 .3 & $\begin{array}{l}\text { Changes initiated because of failure of a project component, subsystem, or system } \\
\text { (including facilities) to meet the acceptance criteria must be evaluated and } \\
\text { corrective actions undertaken by the affected project discipline as directed by } \\
\text { management. }\end{array}$ \\
\hline 21 & 4.3 & $\begin{array}{l}\text { Technical performance measures shall be used within River Protection Project } \\
\text { T\&E planning activities to assess (measure) the evolving capability of the } \\
\text { program- and project-level technical baselines to meet the established functions } \\
\text { and requirements and accomplish the mission. }\end{array}$ \\
\hline 22 & 4.4 & $\begin{array}{l}\text { When the performance requirements have been established, acceptance criteria } \\
\text { shall be developed to provide a performance measure for objectively verifying } \\
\text { that the performance requirements have been satisfied. }\end{array}$ \\
\hline 23 & 4.4 & $\begin{array}{l}\text { Acceptance criteria must be measurable, quantifiable, complete, current, accurate, } \\
\text { and traceable. }\end{array}$ \\
\hline 24 & 4.4 & $\begin{array}{l}\text { Acceptance criteria parameters or measures and tolerance bands shall be clearly } \\
\text { established, documented, accepted, and approved. }\end{array}$ \\
\hline 25 & 4.4 .2 & Acceptance criteria measures and tolerance bands shall be quantitative. \\
\hline 26 & 4.4 .2 & $\begin{array}{l}\text { U.S. Department of Energy, national, or international standards that are expressed } \\
\text { in terms such as "good" or "acceptable" must be translated into measurable, } \\
\text { qualitative criteria. }\end{array}$ \\
\hline 27 & 4.4 .3 & $\begin{array}{l}\text { The set of acceptance criteria (i.e., measures) for each specific requirement must } \\
\text { be complete. }\end{array}$ \\
\hline 28 & 4.4 .3 & $\begin{array}{l}\text { The set of acceptance criteria for each level of test shall be established such that if } \\
\text { the complete set is met, there is reasonable assurance that the end product(s) } \\
\text { satisfy the customer's requirements. }\end{array}$ \\
\hline 29 & 4.4 .4 & $\begin{array}{l}\text { Change control principles and practices shall be used to ensure that acceptance } \\
\text { criteria are current and accurate and that, if project (or test) requirements are } \\
\text { changed, the acceptance criteria will be changed. }\end{array}$ \\
\hline 30 & 4.4 .5 & $\begin{array}{l}\text { System and technical acceptance criteria shall use the same measures (where } \\
\text { appropriate) to define similar parameters. }\end{array}$ \\
\hline 31 & 4.4 .5 & $\begin{array}{l}\text { Acceptance criteria also shall be traceable to the requirement so the completeness } \\
\text { of the acceptance criteria can be ensured. }\end{array}$ \\
\hline 32 & 4.5 & $\begin{array}{l}\text { T\&E planning shall include appropriate turnover testing at the end of the } \\
\text { execution phase in addition to verification conducted during the earlier phases } \\
\text { (Requirements and Design Baseline) to demonstrate and document compliance. }\end{array}$ \\
\hline 33 & 4.5 & $\begin{array}{l}\text { The complete set of verification results shall be reviewed and evaluated against } \\
\text { performance requirements to ensure the results demonstrate compliance as part of } \\
\text { the turnover activities. }\end{array}$ \\
\hline 34 & 4.5 & $\begin{array}{l}\text { The project team must address and resolve any issues noted during this } \\
\text { assessment. }\end{array}$ \\
\hline
\end{tabular}


Table A-1. Requirements Found in this Document (5 sheets).

\begin{tabular}{|c|c|c|}
\hline $\begin{array}{l}\text { Require- } \\
\text { ment } \\
\text { number }\end{array}$ & Section & TEMP requirement \\
\hline 35 & 4.5 .1 & $\begin{array}{l}\text { Qualified people, other than those who designed, who will approve the design, or } \\
\text { who will use the design, shall verify the adequacy of the design. }\end{array}$ \\
\hline 36 & 4.5 .1 & $\begin{array}{l}\text { An organization that is independent of the construction organization shall perform } \\
\text { acceptance inspection of construction, as discussed in HNF-PRO-1819, PHMC } \\
\text { Engineering Requirements. }\end{array}$ \\
\hline 37 & 4.5 .2 & $\begin{array}{l}\text { When acceptance criteria and performance requirements have been established, } \\
\text { specific } T \& E \text { verification methods shall be selected and } T \& E \text { activities planned } \\
\text { and scheduled. }\end{array}$ \\
\hline 38 & 4.5 .5 & $\begin{array}{l}T \& E \text { documentation shall provide traceability among the performance } \\
\text { requirements, } T \& E \text { activities, and } T \& E \text { results to demonstrate that the project end } \\
\text { product(s) meet all acceptance criteria. }\end{array}$ \\
\hline 39 & 4.5 .5 & $\begin{array}{l}\text { The complete set of testing results shall be reviewed against performance } \\
\text { requirements as part of the turnover process for projects and before any readiness } \\
\text { review activities. }\end{array}$ \\
\hline 40 & 4.5 .5 & $\begin{array}{l}\text { Testing results also shall be evaluated against other testing activities and results to } \\
\text { ensure that problems and unacceptable and/or unexpected results encountered in } \\
\text { one series of tests do not impact other testing and verification activities. }\end{array}$ \\
\hline 41 & 4.5 .5 & $\begin{array}{l}\text { If testing (verification) activity results do not comply with requirements, the } \\
\text { results must be reassessed as early as possible to identify alternative approaches } \\
\text { for meeting requirements with a minimum impact on resources, risk, and baseline } \\
\text { activities. }\end{array}$ \\
\hline 42 & 4.5 .6 & $\begin{array}{l}\text { Verification of the acceptability and compatibility of human performance } \\
\text { requirements, training, and person-machine interfaces shall be integrated into } \\
\text { system testing. }\end{array}$ \\
\hline 43 & 4.6 .1 & $\begin{array}{l}\text { A graded approach shall be employed when deciding which designs and } \\
\text { requirements require development testing. }\end{array}$ \\
\hline 44 & 4.6 .1 & $\begin{array}{l}\text { Enabling assumptions and new technologies (and processing operations) shall be } \\
\text { proven at the first opportunity. }\end{array}$ \\
\hline 45 & 4.6 .2 & $\begin{array}{l}\text { Development testing to prove process/architecture design concepts shall be } \\
\text { traceable to test procedures, test documents, and reports that document the } \\
\text { evaluation of results. }\end{array}$ \\
\hline 46 & 4.6 .2 & $\begin{array}{l}\text { Adequate documentation shall be maintained to provide a basis for the technology } \\
\text { and/or architecture selection. }\end{array}$ \\
\hline 47 & 4.7 .1 & $\begin{array}{l}\text { If any of the acceptance criteria are not met at this point, modifications to the } \\
\text { design must be incorporated and re-verified. }\end{array}$ \\
\hline 48 & 4.7 .1 & $\begin{array}{l}\text { Where development testing cannot be performed because of cost or schedule } \\
\text { considerations, or because of an inability to replicate the actual field conditions, } \\
\text { the design must be validated and documented through analysis, simulations, and } \\
\text { design reviews. }\end{array}$ \\
\hline 49 & 4.7 .2 & $\begin{array}{l}\text { Reviews shall be used to determine design performance and conformance with } \\
\text { specified requirements and acceptance criteria by examination of items such as } \\
\text { engineering drawings, analysis results, calculations, flow diagrams, specifications, } \\
\text { and computer programs. }\end{array}$ \\
\hline 50 & 4.7 .2 & Formal periodic design reviews shall be conducted throughout the design process. \\
\hline 51 & 4.7 .2 & $\begin{array}{l}\text { Results of these reviews shall be evaluated and acted upon in accordance with } \\
\text { approved processes and procedures. }\end{array}$ \\
\hline
\end{tabular}


Table A-1. Requirements Found in this Document (5 sheets).

\begin{tabular}{|c|c|c|}
\hline $\begin{array}{l}\text { Require- } \\
\text { ment } \\
\text { number }\end{array}$ & Section & TEMP requirement \\
\hline 52 & 4.7 .4 & $\begin{array}{l}\text { Early in the Detailed Design phase, the project shall prepare, where appropriate, } \\
\text { an operational-focused TEP (a subset of the TEP). }\end{array}$ \\
\hline 53 & 4.7 .4 & $\begin{array}{l}\text { This TEP shall (1) define remaining verification activities required in the pre- } \\
\text { operational and operational acceptance testing phases; and (2) identify verification } \\
\text { products, activities, and the logic sequence that will govern their implementation. }\end{array}$ \\
\hline 54 & 4.7 .4 & $\begin{array}{l}\text { The project TEP provides an overall integration of the products identified in the } \\
\text { operational TEP. This information shall be incorporated into the baseline control } \\
\text { documents. }\end{array}$ \\
\hline 55 & 4.7 .4 & $\begin{array}{l}\text { Test-specific procedures shall be developed early in the Detailed Design } \\
\text { subphase. }\end{array}$ \\
\hline 56 & 4.7 .4 & $\begin{array}{l}\text { In addition, specific acceptance criteria and test measurement parameters shall be } \\
\text { established and incorporated into the test procedures as early as possible. }\end{array}$ \\
\hline 57 & 4.7 .5 & $\begin{array}{l}\text { Qualification testing shall be conducted at levels that exceed required } \\
\text { performance. }\end{array}$ \\
\hline 58 & 4.7 .5 & $\begin{array}{l}\text { When an equipment manufacturer/vendor is selected to supply a component or } \\
\text { subsystem, the performance and testing requirements shall be identified in the } \\
\text { procurement specification and associated contract(s). }\end{array}$ \\
\hline 59 & 4.7 .5 & $\begin{array}{l}\text { Before delivery and acceptance, the vendor shall be required to submit test results } \\
\text { and documentation to the buyer for review and acceptance. }\end{array}$ \\
\hline 60 & 4.7 .6 & $\begin{array}{l}\text { Construction planning shall be included in the appropriate TEP to address } \\
\text { installation of test items and test equipment and to ensure the presence of test } \\
\text { personnel in the construction area who support testing requirements. }\end{array}$ \\
\hline 61 & 4.7 .7 & Duplicate testing to verify the same requirements shall be eliminated. \\
\hline 62 & 4.7 .7 & $\begin{array}{l}\text { Acceptance test reports, including a record copy of the completed ATP, test } \\
\text { deficiencies/resolutions, and records of repairs/modifications and re-testing } \\
\text { performed, shall be required. }\end{array}$ \\
\hline 63 & 4.7 .7 & $\begin{array}{l}\text { Final acceptance test reports shall be submitted to the RPP end-user organization } \\
\text { before the system(s) are accepted for operation. }\end{array}$ \\
\hline 64 & 4.7 .8 & $\begin{array}{l}\text { At the conclusion of the integrated testing, a design and operations team shall } \\
\text { review the project and operational TEPs to verify that required testing has been } \\
\text { completed for each performance requirement, and that it is traceable to an } \\
\text { analysis, calculation record, inspection report, test procedure/report, etc. }\end{array}$ \\
\hline 65 & 4.7 .8 & $\begin{array}{l}\text { This review of the TEP(s) and supporting T\&E documents shall be used as input } \\
\text { to the readiness review process (if an operational readiness review is part of the } \\
\text { specific project scope). }\end{array}$ \\
\hline 66 & 4.7 .9 & $\begin{array}{l}\text { As part of the turnover process (including the acceptance for beneficial use and } \\
\text { operational readiness review processes), the RPP end-user organization shall } \\
\text { review the project documentation submitted as evidence that the physical } \\
\text { system(s) and supporting infrastructure will operate properly and meet } \\
\text { performance requirements. }\end{array}$ \\
\hline 67 & 4.7 .9 & $\begin{array}{l}\text { After each individual system has been accepted through the ATP and OTP process } \\
\text { and the supporting infrastructure elements required for operation have been } \\
\text { verified, an integrated test shall be conducted (where appropriate). }\end{array}$ \\
\hline 68 & 4.8 & $\begin{array}{l}\text { Tests are specific to each facility and shall be planned, managed, reviewed, and } \\
\text { accepted by qualified staff at the facility. }\end{array}$ \\
\hline
\end{tabular}


Table A-1. Requirements Found in this Document (5 sheets).

\begin{tabular}{|c|c|c|}
\hline $\begin{array}{l}\text { Require- } \\
\text { ment } \\
\text { number }\end{array}$ & Section & TEMP requirement \\
\hline 69 & 4.8 & $\begin{array}{l}\text { Facility-specific T\&E management shall ensure that staff use appropriate } \\
\text { approved test procedures and documentation (see the references in Section } 6.0 \text { in } \\
\text { the main text for test activities). }\end{array}$ \\
\hline 70 & 4.8 .1 & $\begin{array}{l}\text { Before startup (during the Design Baseline phase and documented in the } \\
\text { operational TEP), an ongoing program of periodic surveillance testing and post- } \\
\text { maintenance testing must be developed and instituted to ensure the equipment can } \\
\text { continue to perform its design function. The program shall be fully implemented } \\
\text { and verified during the Operations Baseline phase. }\end{array}$ \\
\hline 71 & 4.8 .2 & $\begin{array}{l}\text { T\&E planning shall be performed for major operational activities that will use } \\
\text { installed equipment that has not been subject to a periodic surveillance testing and } \\
\text { preventive maintenance program or that has not been demonstrated previously. }\end{array}$ \\
\hline 72 & 4.8 .8 & $\begin{array}{l}\text { During the deactivation planning stage of a project or facility, a revised } \\
\text { surveillance and maintenance plan shall be developed consistent with the revised } \\
\text { TSRs. }\end{array}$ \\
\hline 73 & 5.0 & $\begin{array}{l}\text { All River Protection Project programs, projects, and facilities/operations shall } \\
\text { generate TEPs to identify required T\&E activities. }\end{array}$ \\
\hline 74 & 5.0 & $\begin{array}{l}\text { The program, project, and operational TEP shall address each requirement (as } \\
\text { appropriate), the verification methods to be used, acceptance criteria used to } \\
\text { demonstrate compliance, the performance period for the activities, and the } \\
\text { estimated cost if the activity is estimated separately from other project activities. }\end{array}$ \\
\hline 75 & 5.1 & $\begin{array}{l}\text { The project TEP(s) shall ensure that each performance requirement is verified at } \\
\text { the appropriate phase of the project/program to minimize the technical and } \\
\text { operational risks. }\end{array}$ \\
\hline 76 & $\begin{array}{l}\text { App. B, } \\
\text { Sect. B2.0 }\end{array}$ & $\begin{array}{l}\text { The T\&E schedule shall identify management decisions that depend on an } \\
\text { evaluation of T\&E results. }\end{array}$ \\
\hline 77 & $\begin{array}{l}\text { App. B, } \\
\text { Sect. B2.0 }\end{array}$ & $\begin{array}{l}\text { T\&E schedule shall include time for reviews, procedure generation, test and re- } \\
\text { test activities, report generation, and external reviews, if appropriate. }\end{array}$ \\
\hline 78 & $\begin{array}{l}\text { App. B, } \\
\text { Sect. B3.0 }\end{array}$ & $\begin{array}{l}\text { The test system description also shall discuss any integration requirements with } \\
\text { other tests or project/operations activities. }\end{array}$ \\
\hline 79 & $\begin{array}{l}\text { App. B, } \\
\text { Sect. B6.0 }\end{array}$ & $\begin{array}{l}\text { This section identifies the principal organizations responsible for planning and } \\
\text { conducting T\&E and includes an organizational chart of the T\&E team(s). }\end{array}$ \\
\hline 80 & $\begin{array}{l}\text { App. B, } \\
\text { Sect. B6.0 }\end{array}$ & $\begin{array}{l}\text { The authority and responsibility for scheduling test resources and management } \\
\text { direction for conducting individual T\&E activities shall be identified. }\end{array}$ \\
\hline 81 & $\begin{array}{l}\text { App. B, } \\
\text { Sect. B11.0 }\end{array}$ & $\begin{array}{l}\text { The T\&E matrix shall specify the acceptance criteria for each performance } \\
\text { criterion. }\end{array}$ \\
\hline 82 & $\begin{array}{l}\text { App. B, } \\
\text { Sect. } 13.0\end{array}$ & $\begin{array}{l}\text { Changes to the functions and requirements, T\&E methods, or acceptance criteria } \\
\text { shall require a revision to the TEP(s). }\end{array}$ \\
\hline nII & \multirow{4}{*}{\multicolumn{2}{|c|}{$\begin{array}{l}=\text { acceptance test procedure } \\
=\text { testing and evaluation } \\
=\text { testing and evaluation plan } \\
=\text { testing and evaluation management plan }\end{array}$}} \\
\hline $\mathrm{T} \& \mathrm{E}$ & & \\
\hline TEP & & \\
\hline & & \\
\hline
\end{tabular}


HNF-2029

Revision 1

\section{A1.0 REFERENCES}

Gibson, E. R., 1998, TWRS Administrative Manual, HNF-IP-0842, Fluor Daniel Hanford, Inc., Richland, Washington.

HNF-PRO-1819, PHMC Engineering Requirements, Fluor Daniel Hanford, Inc., Richland, Washington. 
HNF-2029

Revision 1

\section{APPENDIX B}

ANNOTATED OUTLINE FOR TESTING AND EVALUATION PLANS 
HNF-2029

Revision 1

This page intentionally left blank. 
HNF-2029

Revision 1

\section{APPENDIX B}

\section{ANNOTATED OUTLINE FOR TESTING AND EVALUATION PLANS}

\section{B1.0 PURPOSE}

This section concisely states the purpose of the development and/or operational testing and evaluation plans (TEP). This section also identifies design, procurement, construction, safe conduct of tests, and operational use and support decisions that depend on the testing and evaluation (T\&E) results.

\section{B2.0 PROGRAM SCHEDULE AND MILESTONES}

Integrated project schedules identify the important $T \& E$ events and milestones and include scheduled dates. This section includes important events in the project life cycle that are useful to depict the relationship of T\&E to the overall project schedule. The T\&E schedule shall identify management decisions that depend on an evaluation of $T \& E$ results. The T\&E schedule shall include time for reviews, procedure generation, test and re-test activities, report generation, and external reviews, if appropriate.

\section{B3.0 TEST SYSTEM DESCRIPTION}

This section briefly describes the test system. This section also identifies the relationships and interfaces with major systems and subsystems to the test requirements and functions (and performance requirements). The test system description also shall discuss any integration requirements with other tests or project/operations activities.

\section{B4.0 TESTING AND EVALUATION CONSTRAINTS}

This section identifies constraints that limit the ability of personnel to test under realistic operational conditions. Factors that constrain testing include test item configuration, boundaries, test range, test sequence, environmental conditions, cost, and schedule. This section discusses the test constraints for development testing in the context of the technical and operational risks. This provides the rationale for choosing to forego some or all of the early development T\&E activities instead of follow-on T\&E later in the design or procurement phases or in the acceptance and operational testing phase. 
HNF-2029

Revision 1

\section{B5.0 TEST LOCATIONS}

This section identifies the locations in which testing will be conducted and discusses test facility modifications required for prototype or demonstration tests. This section also addresses the computer codes and special software and hardware required for computer simulations, modeling, and analysis/calculations.

\section{B6.0 TEST MANAGEMENT}

This section identifies the principal organizations responsible for planning and conducting T\&E and includes a chart of the T\&E team(s). The authority and responsibility for scheduling test resources and management direction for conducting individual T\&E activities shall be identified. Organizational responsibilities described in the Testing and Evaluation Management Plan should provide a starting point for preparing this section of the TEP.

\section{B7.0 TRAINING REQUIREMENTS}

This section discusses training and qualification requirements for analysts and testing team members.

\section{B8.0 CRITICAL ISSUES FOR TESTING AND EVALUATION}

This section discusses all critical technical and operational issues that the test planning activities will have to accommodate (see Section 5.1 in the main text).

\section{B9.0 TESTING AND EVALUATION APPROACH}

This section addresses the T\&E approach for verifying major performance requirements or critical issues. This includes the rationale for selecting analysis or testing methods, actual infield or mockup tests, testing of individual pieces of prototypical equipment or integrated system mockup/demonstration testing, and phasing and grouping of T\&E events. The T\&E matrix shall specify the $T \& E$ approach selected for each performance requirement. This section also discusses how the overall $\mathrm{T} \& \mathrm{E}$ approach provides confidence that the project and/or facility modification will succeed. 
HNF-2029

Revision 1

\section{B10.0 PERFORMANCE REQUIREMENTS}

This section lists the upper-level technical and operational performance requirements and identifies technical performance measures. If applicable, a T\&E matrix, which contains more detailed performance requirements, is referenced.

\section{B11.0 TEST ACCEPTANCE CRITERIA}

This section provides thresholds, limits, and allowable variances for each performance requirement. The T\&E matrix shall specify the acceptance criteria for each performance criterion.

\section{B12.0 DATA MANAGEMENT}

This section discusses the data that will be collected, the manner in which these data will be recorded and placed in the document control system, and the manner in which results will be evaluated.

\section{B13.0 TESTING AND EVALUATION MATRIX}

A T\&E matrix, which is a required section in a TEP, provides a map from the requirements to the selected $T \& E$ method(s) and acceptance criteria. A simple $T \& E$ matrix that lists requirements to be tested in one column, and test methods, acceptance criteria, and test procedures in the remaining columns, can be used to satisfy this content requirement.

An example of a detailed T\&E matrix that relates to qualification of design is in Attachment X, Section 4.0 of Level 1 Specifications or the "Quality Conformance Inspection Matrix" of HNF-SD-WM-TRD-007, System Specification for the Double-Shell Tank System (Grenard et al. 1998) Once the appropriate T\&E directives and/or procedures have been defined and incorporated into the T\&E matrix, completed T\&E documentation can be traced to the performance requirements through the T\&E matrix. Changes to the functions and requirements, T\&E methods; or acceptance criteria shall require a revision to the TEP(s).

\section{B14.0 REFERENCES}


HNF-2029

Revision 1

Grenard, C. E., R. D. Claghorn, T. J. Conrads, and M. A. deLamare, 1998, System Specification for the Double-Shell Tank System, HNF-SD-WM-TRD-007, prepared by COGEMA Engineering, Inc., Numatec Hanford Corporation, and TRW for Fluor Daniel Hanford, Inc., Richland, Washington. 
HNF-2029

Revision 1

\section{DISTRIBUTION}

Onsite

1

1

2

1
U.S. Department of Energy, Richland Operations Office

Public Reading Room

$\mathrm{H} 2-53$

Lockheed Martin Hanford Corporation

C. E. Wilson

.H7-06

Lockheed Martin Services, Inc.

S. R. Nelson

Document Processing Center

G3-36

A3-94

Pacific Northwest National Laboratory

Hanford Technical Library

P8-55
Dist-1 
HNF-2029

Revision 1

This page intentionally left blank.

Dist-2 